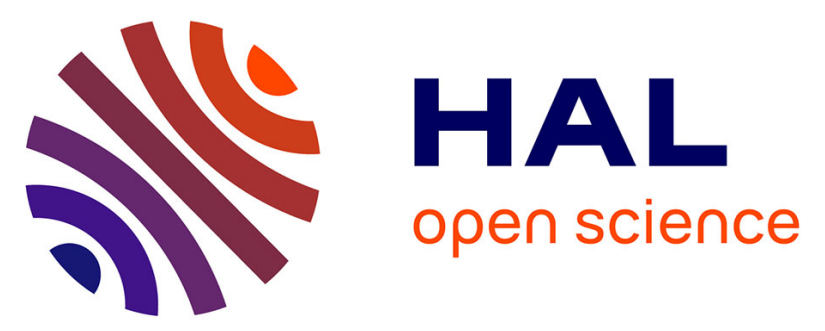

\title{
Sidi M'Barek: a representative example of the Moroccan massive sulphide deposits
}

\author{
Abdelhak Outigua, Abderrahim Essaifi, Michel Corsini, Mohamed
}

Outhounjite, Mohamed Zouhair

\section{To cite this version:}

Abdelhak Outigua, Abderrahim Essaifi, Michel Corsini, Mohamed Outhounjite, Mohamed Zouhair. Sidi M'Barek: a representative example of the Moroccan massive sulphide deposits. The Geological Society, London, Special Publications, 2020, 502, pp.SP502-2019-65. 10.1144/SP502-2019-65 . hal02471637

\section{HAL Id: hal-02471637 \\ https://hal.science/hal-02471637}

Submitted on 8 Feb 2020

HAL is a multi-disciplinary open access archive for the deposit and dissemination of scientific research documents, whether they are published or not. The documents may come from teaching and research institutions in France or abroad, or from public or private research centers.
L'archive ouverte pluridisciplinaire HAL, est destinée au dépôt et à la diffusion de documents scientifiques de niveau recherche, publiés ou non, émanant des établissements d'enseignement et de recherche français ou étrangers, des laboratoires publics ou privés. 


\title{
Geological Society, London, Special Publications
}

\section{Sidi M'Barek: a representative example of the Moroccan massive sulphide deposits}

\author{
Abdelhak Outigua, Abderrahim Essaifi, Michel Corsini, Mohamed Outhounjite \\ \& Mohamed Zouhair
}

DOI: https://doi.org/10.1144/SP502-2019-65

Received 23 May 2019

Revised 7 October 2019

Accepted 7 November 2019

(C) 2020 The Author(s). Published by The Geological Society of London. All rights reserved. For permissions: http://www.geolsoc.org.uk/permissions. Publishing disclaimer:

www.geolsoc.org.uk/pub_ethics

To cite this article, please follow the guidance at

https://www.geolsoc.org.uk/ /media/Files/GSL/shared/pdfs/Publications/AuthorInfo_Text.pdf?la=en

\section{Manuscript version: Accepted Manuscript}

This is a PDF of an unedited manuscript that has been accepted for publication. The manuscript will undergo copyediting, typesetting and correction before it is published in its final form. Please note that during the production process errors may be discovered which could affect the content, and all legal disclaimers that apply to the book series pertain.

Although reasonable efforts have been made to obtain all necessary permissions from third parties to include their copyrighted content within this article, their full citation and copyright line may not be present in this Accepted Manuscript version. Before using any content from this article, please refer to the Version of Record once published for full citation and copyright details, as permissions may be required. 
Downloaded from http://sp.lyellcollection.org/ at Universite Nice Sophia Antipolis (ISTEX) on February 6, 2020

\title{
Sidi M'Barek: a representative example of the Moroccan massive sulphide deposits
}

\author{
Abdelhak Outigua ${ }^{1,2}$, Abderrahim Essaifi $^{2}{ }^{*}$, Michel Corsini $^{3}$, Mohamed Outhounjite $^{2} \&$ Mohamed \\ Zouhair $^{2}$ \\ ${ }^{1}$ Geology department, Cadi Ayyad University, BP. 2390, Marrakech, Morocco \\ ${ }^{2}$ Managem Group, BP. 5199, Casablanca 20100, Morocco \\ ${ }^{3}$ Geoazur, CNRS UMR6526, Université Nice Sophia Antipolis, Valbonne, France \\ *Corresponding author (email: essaifi@uca.ac.ma)
}

abbreviated title: Sidi M'Barek massive sulphide deposit

\begin{abstract}
In addition to a Zn-rich lens representing the northern prolongation of the Draa Sfar volcanogenic massive sulphide deposit, the Sidi M'Barek deposit includes $\mathrm{Cu}$-rich lenses in which gold is being recovered profitably as a by-product. The Cu-rich mineralization is composed of numerous structurally controlled veins whose morphology suits that of a lode rather than that of a stratiform orebody. Although the $\mathrm{Cu}$-rich and $\mathrm{Zn}$-rich orebodies are dominated by pyrrhotite, pyrrhotite is coarser grained in the $\mathrm{Cu}$-rich lenses and mineralization is polyphase. Pyrrhotite is deformed and recrystallized; it is crosscut and replaced by pyrite infilling veins. Pyrite crystallizes also along the $S_{1}$ cleavage and in pressure shadows around bioclasts in the disseminated ore. Chalcopyrite veins postdate both the pyrrhotite and pyrite phases.

The concentration of $\mathrm{Co}$ and $\mathrm{Au}$ is higher in the $\mathrm{Cu}$-rich lenses relative to the $\mathrm{Zn}$-rich lenses, which have higher concentrations in $\mathrm{Pb}, \mathrm{Ag}$ and As. Pyrite and pyrrhotite have distinct sulphur and lead isotopic signatures. We propose a polygenetic model in which a pre-existing syngenetic pyrrhotiterich mineralization is remobilized in shear zones during a major ductile deformation event allowing deposition of pyrite. The shear zones were reopened during a late ductile-brittle deformation event allowing deposition of chalcopyrite.
\end{abstract}

Keywords: Massive sulphide; Pyrrhotite; Draa Sfar; Hercynian; Morocco

Located in the Central Jebilet, the Draa Sfar district contains two deposits: a southern deposit called Tazakourt, and a northern deposit called Sidi M'Barek. These two deposits are separated at the surface by the Tensift River, but there is no structural discontinuity between the orebodies. The Tazakourt orebody consists of one Zn-rich lens that extends N-S for $1.5 \mathrm{~km}$ and has been delineated between -50 and $-1500 \mathrm{~m}$ levels and remains open at depth. It represents the main ore lens at Draa Sfar and has been exploited since the commencement of mining at the Draa Sfar deposit in 2004. At that time the Sidi M'Barek orebody had not yet been delineated, and was thought to be composed of 
Downloaded from http://sp.lyellcollection.org/ at Universite Nice Sophia Antipolis (ISTEX) on February 6, 2020

two massive sulphide lenses, a western or upper Zn-rich lens interpreted to be the continuation of the Tazakourt ore lens, and an eastern or lower Cu-rich lens (Marcoux et al. 2008).

The previous studies on the Draa Sfar deposit were concentrated on the Zn-rich lens (Moreno et al. 2008; Ben Aissi et al. 2005; Hibti 2001; Rziki 2012). This deposit was classified as a VMS deposit (Belkabir et al. 2008; Marcoux et al. 2008; Moreno et al. 2008), but a feeder or stockwork sulphide zone has not been identified. Because the lower or eastern $\mathrm{Cu}$-rich lens contains bismuth selenides, Marcoux et al. (2008) suggested that it may represent for the Draa Sfar ore deposit the upper part of a stockwork zone that has been strongly transposed by deformation. Marcoux et al. (2008) noticed however that the lead isotopic signature indicate that two types of hydrothermal fluids were involved in the Draa Sfar deposit, a less radiogenic fluid $\left({ }^{206} \mathrm{~Pb} /{ }^{204} \mathrm{~Pb} \sim 18.30\right)$ that formed the $\mathrm{Zn}$-rich lens and a more radiogenic fluid $\left({ }^{206} \mathrm{~Pb} /{ }^{204} \mathrm{~Pb} \sim 19.01\right)$ that formed the $\mathrm{Cu}$-rich lens. They concluded that between the formation of the initial $\mathrm{Zn}$-rich and subsequent more $\mathrm{Cu}$-rich orebodies, hydrothermal circulation may have changed to reflect a different source rock or the fluid may have had a higher temperature increasing its ability to dissolve and carry copper. The differences between the Tazakourt and the Sidi M'Barek deposits are also recorded in the hydrothermal alteration of the host rocks, which is characterized by the dominance of chlorite in the footwall and sericite in the hanging wall of the Tazakourt orebody while the Sidi M'Barek orebody is characterized by a sericite-dominated alteration in both the footwall and the hanging wall (Belkabir et al. 2008). These differences led Belkabir et al. (2008) to interpret the Tazakourt and Sidi M'Barek orebodies as representing respectively the proximal and the distal volcanic environments of the Draa Sfar VMS deposit.

The commencement of mining at the Sidi M'Barek deposit in 2011 has resulted in increased accessibility to the deposit and its host rocks allowing new data to be obtained from underground and surface mapping and from drill cores. Presently the deposit is composed of a $\mathrm{Zn}$-rich lens and a dozen of $\mathrm{Cu}$-rich lenses, the latter are also rich in cobalt and gold. These new data for the deposit have significant implications on the genesis of the Draa Sfar deposit and other massive sulphide deposits of the Marrakech area. Indeed, these deposits are classified as either Zn-rich deposits (e.g. Tazakourt, Hajjar, Koudiat Aicha) or Cu-rich deposits (e.g. Kettara). There is an ongoing debate on the genesis of these deposits, with a syngenetic hypothesis that classifies the deposits as VMS deposits formed at or below the seafloor in an anoxic basin (Belkabir et al. 2008; Marcoux et al. 2008; Moreno et al. 2008) and an epigenetic hypothesis implying that the deposits formed during regional deformation and metamorphism (Essaifi \& Hibti 2008; N'diaye et al. 2016). In addition, a multistage evolution of the Moroccan massive sulphide deposits has recently been proposed (Essaifi et al. 2019).

In order to better understand the relationship between the $\mathrm{Zn}$-rich and the $\mathrm{Cu}$-Au-rich mineralization, deformation and metamorphism, this paper compares the structures, textures, mineralogy and geochemistry of the Zn-rich and Cu-rich lenses of the Sidi M'Barek orebody, and discusses the temporal relationships between each type of mineralization, alteration, metamorphism and 
Downloaded from http://sp.lyellcollection.org/ at Universite Nice Sophia Antipolis (ISTEX) on February 6, 2020

deformation. The intent is to establish the timing and origin of each mineralization relative to the regional tectono-sedimentary evolution of the Jebilet massif.

\section{Geological framework}

The Draa Sfar Cluster is located $15 \mathrm{~km}$ to the northwest of Marrakech, along the southern margin of the Jebilet massif, in the southern part of the Moroccan Meseta. The Jebilet massif provides a wellexposed cross-section across the western Meseta (Huvelin 1977; Essaifi et al. 2001), which is separated from the eastern Meseta by the middle Atlas (Fig. 1a). The massif is divided in three structural units (Fig. 1b): the Central Jebilet, the Western Jebilet and the Eastern Jebilet.

The Central Jebilet unit comprises sedimentary rocks of Visean age (Huvelin 1977), which have been metamorphosed to low grade and extensively deformed in the Variscan orogeny (Huvelin 1977; Essaifi et al. 2001; Delchini et al. 2016). The Western Jebilet is separated from the Central Jebilet by a dextral thrust-wrench fault (Mayol \& Muller 1985; Le Corre \& Bouloton 1987), part of the Western Meseta Shear Zone (Piqué et al. 1980). The Western Jebilet unit is part of the Coastal Block, and is composed of Cambro-Ordovician sedimentary rocks that were uplifted in the Late Devonian and only weakly deformed in the Variscan (Huvelin 1977; Piqué \& Michard 1989). The Eastern Jebilet is separated from the Central Jebilet by the Marrakech Shear Zone (Lagarde \& Choukroune 1982; Essaifi et al. 2001). The Eastern Jebilet unit contains a Carboniferous sedimentary sequence, the 'Kharrouba Flysch' (Huvelin 1977) which grades from turbidites to tidally-influenced shallow marine deposits (Graham 1982a, b; Beauchamp 1984; Beauchamp \& Izart 1987). The Eastern Jebilet is overlain by tectonically-emplaced nappes of Ordovician to Early Carboniferous sedimentary rocks with a chaotic basal breccia (Graham 1982a, Izart et al. 1997). These nappes mark the onset of the closure of the Mesetian basin (Lagarde 1989; Michard et al. 2010; Hoepffner et al. 2005). Westphalian-Permian continental conglomerates (Huvelin 1977) rest unconformably upon the Hercynian folded sequence in the Eastern and Western Jebilet units.

The Central Jebilet unit, which hosts the Draa Sfar deposit (see Fig. 2), is a thick (>1000 m) largely low-grade metamorphosed Upper Visean metasedimentary sequence called the Sarhlef schists (Huvelin 1977). The Sarhlef schists are dominated by shales with subsidiary limestone and sandstone beds deposited in an anoxic platform, with the interbedded sandstones representing storm deposits (Beauchamp et al. 1991; Beauchamp \& Izart, 1987). The Sarhlef schists host a bimodal magmatism and have been described as a metamorphosed volcano-sedimentary sequence, with shales interbedded with volcanic and volcaniclastic units (Huvelin 1977; Bordonaro 1983). In fact, the majority of the igneous rocks in the Central Jebilet are intrusive rocks with only minor rhyolitic and rhyodacitic lavas and volcaniclastic units (Aarab \& Beauchamp 1987; Essaifi et al. 2014). The most significant area of extrusive volcanic rocks forms a rhyolitic dome near the Draa Sfar deposit, on the southern edge of the Central Jebilet exposure (Belkabir et al. 2008). 
Downloaded from http://sp.lyellcollection.org/ at Universite Nice Sophia Antipolis (ISTEX) on February 6, 2020

The Variscan magmatism in Central Jebilet can be divided into two groups. The first group is a bimodal association of numerous mafic-ultramafic layered intrusions, sills and dykes with alkaline microgranitic sheet-like intrusions, dykes and domes (Essaifi et al. 2014). A microgranitic intrusion (Koudiat Bouzlaf) was dated to $330.5+0.68 /-0.83 \mathrm{Ma}$ (U-Pb on zircon; Essaifi et al. 2003) while the rhyolitic dome of Draa Sfar gave an age of $331.7 \pm 7.9 \mathrm{Ma}$ (Ar-Ar on white mica; Marcoux et al. 2008), and more recently a sample from the Koudiat Hamra intrusion has been dated to $345 \pm 2 \mathrm{Ma}$ (SHRIMP U/Pb dating; Delchini et al. 2018). The second group of intrusions comprises two cordierite-bearing granodioritic plutons, crosscut by leucogranitic sheets and stocks. The granodioritic plutons have been dated to $327 \pm 4 \mathrm{Ma}$ and the leucogranites to $295 \pm 15 \mathrm{Ma}$ (whole-rock Rb-Sr ages; Mrini et al. 1992), although more recent U-Pb SHRIMP dating has suggested somewhat older ages of 358-336 Ma for the granodiorites (Delchini et al. 2018). In summary, a sustained and long-lasting magmatic activity occurred in the Jebilet massif between $358 \pm 7 \mathrm{Ma}$ and ca. $300 \mathrm{Ma}$ (Mrini et al. 1992; Essaifi et al. 2003; Delchini et al. 2018). The felsic magmatism is characterized by a temporal evolution from magmas of a hybrid origin to magmas of a pure crustal origin reflecting a lithosphere that is heated from below (Essaifi et al. 2014).

The NNE-trending dextral thrust-wrench West Moroccan Shear Zone and the NW-trending sinistral Marrakech Shear Zone (Figs 1-2) delimit a triangular block (Central Jebilet) where the Sarhlef schists have undergone low-grade metamorphism and deformation during the Variscan orogeny (Huvelin 1977; Bordonaro 1983; Essaifi et al. 2001; Delchini et al. 2018). The main regional schistosity $\left(S_{1}\right)$ typically trends NNE-SSW and is axial planar to a series of open upright $\mathrm{F}_{1}$ folds (Bordonaro 1983; Essaifi et al. 2001). This schistosity curyes into a series of typically N-S trending sinistral shear zones, interconnected by E-NE dextral shear zones (Essaifi et al. 2001; N'diaye et al. 2016). These minor shear zones are shifted towards the Marrakech Shear Zone, which is the largest shear zone in Central Jebilet. The shear zones are associated with an intensification of foliations, tightening of folds and development of stretching lineations, which can be considered as related to a $\mathrm{D}_{2}$ phase (Lagarde \& Choukroune 1982; Essaifi \& Hibti 2008). Brittle shear zones are superimposed on the ductile structures and/can be ascribed to a $\mathrm{D}_{3}$ phase. Overall, these structures reflect coeval transpression, vertical extrusion and south-directed lateral escape that were facilitated by the bounding conjugate WMSZ and MSZ (Essaifi et al. 2003). Absolute and relative timing constraints show that transpression was sustained from ca. 330 Ma to 300 Ma (Huon et al. 1987; Mrini et al. 1992; Essaifi et al. 2003; Delchini et al. 2018).

An important feature of Central Jebilet is the presence of numerous polymetallic massive sulphide deposits (Fig. 2). These deposits are aligned along three major lineaments trending N-S to NE-SW (Bernard et al. 1988; Essaifi \& Hibti 2008; Maacha et al. 2017). They are typically pyrrhotitedominated, vertical or steeply dipping, and most of them have been classified as VHMS (Bernard $e t$ al. 1988; Zouhry 1998; Belkabir et al. 2008; Marcoux et al. 2008; Moreno et al. 2008; Lotfi et al. 
Downloaded from http://sp.lyellcollection.org/ at Universite Nice Sophia Antipolis (ISTEX) on February 6, 2020

2008). They are affected by Variscan deformation (Bernard et al. 1988; Marcoux et al. 2008; N'diaye et al. 2016; Admou et al. 2018) and show a polyphase mineralization (Lusty et al. 2015; Essaifi et al., 2019). According to the geochemical classification of VHMS deposits (Franklin et al. 1981; Large 1992), the major massive sulphide deposits of Central Jebilet belong either to the $\mathrm{Pb}-\mathrm{Zn}-\mathrm{Cu}$ type (Tazakourt, Koudiat Aicha) or the Cu-type (Kettara, Sidi M'Barek) (Essaifi et al. 2019).

\section{Methods}

This study is based on lithological and structural mapping of the subsurface exploitation levels (underground galleries at $-35,-75,-90,-110,-130 \mathrm{~m}$ ) and logging of drill cores. Samples were collected from both the mine levels and the drill cores and used for petrographical, mineralogical and geochemical studies. Ore mineralogy and textural relationships were studied by transmitted and reflected light microscopy in 70 thin and polished sections, and complemented by Scanning Electron Microscopy (SEM) at Cadi Ayyad University and the Reminex Research Centre (Marrakech).

The chemical compositions of the sulphides were determined at Service CAMPARIS CNRS-UPMCIPGP Campus Jussieu (Paris, France) using a Cameca SX-100 Electron Probe Microanalyzer (EPMA) equipped with five wavelength-dispersive spectrometers, under a $1 \mu \mathrm{m}$ diameter beam with a voltage of $15 \mathrm{kV}$, a current of $100 \mathrm{nA}$, and counting time adjusted to $60 \mathrm{~s}$.

Whole-rock geochemical data were determined at the Reminex Research Centre by ICP-AES method using the same procedures as those described by Oummouch et al. (2017). Sulphur isotopes of pyrrhotite, chalcopyrite and pyrite for the Sidi M'Barek samples have been determined by Essaifi et al. (2019) while lead isotopes of sulphide samples have been determined by Marcoux et al. (2008).

\section{Geology of the deposit}

\section{Morphology of the mineralized lenses}

The metasedimentary lithologies in the Draa Sfar district include carbonaceous metapelites to the west and sandy metapelites to the east (Fig. 3). These formations are steeply east-dipping and display a layer-parallel $S_{1}$ foliation. In the less deformed metasedimentary rocks, structural relationships indicate that the strata are overturned and younger to the west. The southern part of the district is characterized by the presence, within the sandy metapelites, of a rhyodacitic dome and associated volcaniclastic rocks. These subvolcanic lithologies are folded about a north-trending F1 anticline that places the Draa Sfar district on the west limb of this overturned fold (Belkabir et al. 2008; Rziki 2012). A mafic intrusion composed of coarse-grained to porphyritic gabbros occurs in the carbonaceous metapelites in the southern part of the district.

The Draa Sfar Cluster includes a southern deposit called Tazakourt and a northern deposit called Sidi M'Barek, which are separated by the Tensift River. The Tazakourt deposit consists of one Zn-rich lens that has an average thickness of $20 \mathrm{~m}$ while the Sidi M'Barek deposit consists of a dozen of small lenses including one $\mathrm{Zn}$-rich lens and several Cu-rich lenses (Figs 3-6). The estimated resources of the 
Downloaded from http://sp.lyellcollection.org/ at Universite Nice Sophia Antipolis (ISTEX) on February 6, 2020

$\mathrm{Zn}$-rich lens are $19 \mathrm{Mt}$ of ore grading $3.8 \% \mathrm{Zn}, 1.2 \% \mathrm{~Pb}$, and $0.35 \% \mathrm{Cu} ; 6 \mathrm{Mt}$ has already been extracted since 2004. The total resources of the Cu-rich lenses of Sidi M'Barek are estimated to $1 \mathrm{Mt}$ of ore grading $0.2 \% \mathrm{Zn}, 0.25 \% \mathrm{~Pb}$ and $2 \% \mathrm{Cu}$.

The Sidi M'Barek orebody has a well-developed gossan extending to a depth of $20 \mathrm{~m}$. The mineralized lenses reach $400 \mathrm{~m}$ in length and $10 \mathrm{~m}$ in thickness. These lenses are presently known until a depth of $800 \mathrm{~m}$. The mineralized lenses are hosted by a metasedimentary lithostratigraphic succession of overturned, steeply east-dipping formations composed of carbonaceous metapelites to the west and sandy metapelites containing siltstone and bioclastic beds to the east (Figs 3-6). These sedimentary formations are crosscut by numerous mafic dykes, 0.5 to $3 \mathrm{~m}$ thick. The carbonaceous metapelites are characterized by the presence of millimeter thick beds and veins of calcite within a fine-grained schistose assemblage of muscovite, quartz, calcite, chlorite, titanite and leucoxene. The composition of the carbonaceous metapelites is richer in $\mathrm{CaO}$ (generally $>1 \%$ ) than the sandy metapelites $(<1 \%)$. Most of the $\mathrm{Cu}$-rich lenses are located within the sandy metapelites while the $\mathrm{Zn}$ rich lens is located to the west of the $\mathrm{Cu}$-rich lenses, near the boundary between the sandy metapelites and the carbonaceous metapelites. The carbonaceous metapelites represent a distinct stratigraphic marker at the district of the Draa Sfar. They are located to the top of the Zn-rich lens in both the Koudiat Tazakourt and Sidi M'Barek deposits and thus represent the hanging wall of the Zn-rich massive sulphide lens while the sandy metapelites represent its footwall lithofacies (Belkabir et al. 2008; Rziki 2012).

The Zn-rich massive sulphides of Sidi M'Barek form a $400 \mathrm{~m}$-long NNE striking lens that is dismembered by cross-faults into several smaller lenses (Fig. 4). This lens is steeply dipping and has an average thickness of $5 \mathrm{~m}$ (Fig. 6). It is composed of massive pyrrhotite containing disseminations of sphalerite, chalcopyrite, galena and arsenopyrite. The Zn-rich lens is located in the northern prolongation of the Tazakourt $\mathrm{Zn}$-rich lens and there is no structural discontinuity between the two lenses (Fig. 3). Like the Tazakourt orebody, the Zn-rich lens is located at the contact between the carbonaceous and the sandstone metapelites and has a sheet-like morphology. Hence it was interpreted to represent the continuation of the Tazakourt orebody (Belkabir et al. 2008; Marcoux et al. 2008). The Zn-rich lens pinches out $400 \mathrm{~m}$ to the north of the Tensift River and exists only as disseminated sulphides within the host schists northwards.

The Cu-rich massive sulphides form several N-S to NNE subvertical small lenses ( $<150 \mathrm{~m}$ long and < 10 m-thick). The number of $\mathrm{Cu}$-rich lenses increases from one principal lens in the southern part to several lenses in the northern part of the deposit (Figs 4-6). The Cu-rich lenses are composed of massive pyrrhotite containing disseminations of chalcopyrite or banded ore showing alternation of chalcopyrite bands with pyrite- and/or pyrrhotite rich-bands. Recent drill cores intercepted Cu-rich lenses to the south of the Tensift River and confirm the structural continuity between the Tazakourt 
Downloaded from http://sp.lyellcollection.org/ at Universite Nice Sophia Antipolis (ISTEX) on February 6, 2020

and the Sidi M'Barek ore deposits. The prolongation of the $\mathrm{Cu}$-rich lenses further north of the explored area is yet to be delineated.

\section{Deformation of the mineralized lenses}

The most prominent structural feature in the host rocks of the Sidi M'Barek deposit is a penetrative N$\mathrm{S}$ trending (N175 to $\mathrm{N} 25^{\circ}$ ), steeply east-dipping $\left(70-85^{\circ}\right)$ regional $\mathrm{S}_{1}$ cleavage. Deformation is very heterogeneous and strain intensity variations are recorded along the drill cores where centimeter to meter-scale high strain zones contrast with low strain domains. These strain variations are clearly illustrated in the carbonate beds where highly deformed zones contain echinoderm fossils with boudinage structures and well-developed pressure shadows contrast with low strain zones where fossils are almost spherical without any deformation. The highly deformed zones form anastomosed shear bands that bound lenticular domains of weakly deformed rocks. This structural pattern is similar to that described at different scales in other Moroccan massive sulphide deposits (Admou et al. 2018; N'diaye et al. 2016) and at the scale of Central Jebilet (Essaifi et al. 2001) where anastomosed shear zones bound weakly deformed domains. Locally, the regional $S_{1}$ cleavage bears a gently plunging stretching lineation. The Sidi M'Barek deposit is also characterized by the presence of an $\mathrm{S}_{2}$ crenulation cleavage trending E-W and superimposed on the $S_{1}$ penetrative cleavage (Fig. 4).

Numerous brittle-ductile and brittle shear zones are well developed in the Sidi M'Barek deposit. The brittle behavior is indicated by striations along fault planes and by the occurrence of numerous veins. The major faults are $\mathrm{N} 160^{\circ}$ to N-S trending dextral strike-slip faults that show striations gently plunging to the north. These faults offset the $\mathrm{Zn}$-rich lens and bound the $\mathrm{Cu}$-rich lenses. The other brittle faults can be grouped into NW dextral faults and NE trending sinistral faults that cut across the mineralized lenses (Fig. 4). These faults are respectively synthetic and antithetic to the major $\mathrm{N} 160^{\circ}$ to N-S dextral faults.

The Zn-rich massive sulphides of Sidi M'Barek are highly deformed and are affected by ductile shearing and $\mathrm{P}_{2}$ folds (Fig. 7b). They include elliptical fragments of the host rocks, which are elongated concurrently to the regional $S_{1}$ cleavage (Fig. $7 b, g$ ). Centimeter to millimeter scale elliptical nodules of pyrrhotite are common in the host rocks at the boundaries of the zincian lens, especially at its footwall. The thickness of the lens varies along strike and depth from a few centimeters to $10 \mathrm{~m}$. In the zones where the Zn-rich lens pinches out, the sulphides remain as disseminated minerals within the host metapelites. This thickness variation is similar to that described in the Tazakourt orebody, and related to a "swell and pinch geometry" by Belkabir et al. (2008) and Marcoux et al. (2008).

Ductile deformation in the Zn-rich lens is marked by flattening of the sulphides and associated minerals along a well-defined $S_{1}$ cleavage. Asymmetric pressure shadows are developed around sphalerite and arsenopyrite grains (Fig. 7c-f) while chalcopyrite, galena and pyrrhotite are elongated 
Downloaded from http://sp.lyellcollection.org/ at Universite Nice Sophia Antipolis (ISTEX) on February 6, 2020

along the $\mathrm{S}_{1}$ cleavage (Fig. $7 g, h$ ). The schistose fabric is also indicated by the elliptical shape of the non-sulphide minerals and the inclusions of the host rocks (Fig. 7g). The deformation has led to the formation of a mylonitic fabric with development of $\mathrm{C}$ and $\mathrm{C}$ ' shearing planes and $\mathrm{P}_{2}$ microfolds. A faint but recognizable compositional banding marked by variations in the proportions of sulphide minerals characterizes the Zn-rich lens (Fig. 7a). Although it resembles primary bedding, this mineral banding with development of centimeter scale sphalerite-rich bands alternating with pyrrhotite-rich bands is unlikely to be syngenetic in origin because the layering is parallel to the schistose fabric and primary textures are not observed in the orebodies. Within the pyrrhotite-rich bands, pyrrhotite is finegrained ( $\mathrm{mm}$ in size), equigranular and displays polygonal textures with $120^{\circ}$ triple junctions that are indicative of recrystallization under low-grade metamorphic conditions (Gilligan \& Marshall 1987). These features are similar to those described in the Tazakourt orebody and inferred to be tectonic in origin (Marcoux et al. 2008).

The $\mathrm{Cu}$-rich lenses present sigmoidal shapes and sharp contacts with the host rocks. In the extremities of the ore lenses, the sulphides form thin layers that can be followed for more than 100 meters along strike (Fig. 4). Even though these sulphide layers are parallel to the $S_{1}$ cleavage, they are not boudinaged. These extremities are marked by a quartz-sulphide association that evolves to disseminated sulphides within the host metapelites (Fig. 8a). They display centimer-scale lozengeshaped areas that correspond to right lateral pull-apart (extensional relay) traps where the sulphides are concentrated (Fig. 10c). The superposition of sigmoidal pull-apart formation on earlier shearing deformational event has been clearly observed in these areas. A similar pattern occurs at a larger scale where the central parts of the ore lenses are not affected by ductile deformation and the inclusions of the host rocks within the sulphides are equant and randomly oriented. A subvertical mineral banding marked by alternating bands of chalcopyrite and pyrrhotite is commonly present near the boundaries of the lenses (Fig. 8b). This banding is curvilinear and locally discordant on the $\mathrm{S}_{1}$ cleavage in the host rocks. As the lenses are bounded by faults, their general sigmoidal shape can be interpreted as a pull-apart trap indicating emplacement between 'en echelon' N-S to NNW dextral faults.

The sulphide textures in the $\mathrm{Cu}$-rich lenses are dominated by open space filling textures. The central parts of the lenses are characterized by massive pyrrhotite with disseminated chalcopyrite, while the outer parts of the lenses present a "mineral banding" with alternation of centimeter-scale chalcopyriterich bands with pyrite- and/or pyrrhotite-rich bands. In contrast with the Zn-rich lens, this mineral banding is not related to a tectonic banding because the pyrite and chalcopyrite mineralization lack features of ductile-deformation. Pyrite fills veins that crosscut pyrrhotite while pyrite is in turn crosscut by chalcopyrite (Fig. $8 e, f$ ). Chalcopyrite includes arsenopyrite and sphalerite grains and host rock fragments. The host rock inclusions within chalcopyrite are equant and pressure shadows are absent around arsenopyrite or sphalerite grains (Fig. $8 g$ ). This indicates that the pyrite- and chalcopyrite-rich bands escaped the ductile deformation recorded in the pyrrhotite-rich bands. Thus 
Downloaded from http://sp.lyellcollection.org/ at Universite Nice Sophia Antipolis (ISTEX) on February 6, 2020

pyrite and chalcopyrite bands represent open-space fillings with crystallization in fluid-filled cavities (Robert \& Brown 1986; Touringy et al. 1993), most likely by a crack-seal mechanism.

Pyrrhotite in the $\mathrm{Cu}$-rich lenses is typically recrystallized, coarse-grained (1-5 $\mathrm{mm}$ long) and displays an elongation most likely representing a tectonic cleavage (Fig. $8 c, d$ ). Locally late-stage twins and fractures are also developed in pyrrhotite. The pyrite-bearing veins are almost perpendicular to this tectonic cleavage and they are filled by pyrite along the vein boundaries while carbonates are located in the center of the veins (Fig. 8e). A replacement of pyrrhotite by pyrite occurs along the vein boundaries and progresses along the tectonic cleavage, which indicates that the dilation direction was almost orthogonal to the vein boundaries. The relationship between deformation and pyrite deposition is clearly illustrated at the extremities of the mineralized lenses where the sulphide minerals are disseminated within the host rocks. Here pyrite shows a syn-tectonic growth indicated by stretching along the $S_{1}$ cleavage and crystallization in pressure shadows around fossil clasts (Fig. 8h). Chalcopyrite develops as patches and veins invading both pyrite and pyrrhotite, and is crosscut by later veins of carbonates (Fig. 8f). The chalcopyrite veins are mostly parallel to the tectonic cleavage indicated by the elongation of pyrrhotite grains and by the $S_{1}$ cleavage in the host rocks. These features indicate coupled dilation and replacement of massive sulphide ores in the $\mathrm{Cu}$-rich lenses.

To conclude three stages of sulphide mineralization can be distinguished in the Sidi M'Barek deposit (Fig. 9): (i) a pre- to syn-tectonic stage during which pyrrhotite precipitated together with small amounts of sphalerite, galena and arsenopyrite. The evidence for pre-tectonic sulphides is indicated by the development of pressure shadows around sphalerite and arsenopyrite grains in the Zn-rich lens and disseminated ore; (ii) a syn-tectonic to late-tectonic pyrite-dominated stage during which pyrite precipitated along the $S_{1}$ cleavage plane, in pressure shadows around competent objects and in syn- to late-tectonic veinlets; (iii) a late- to post-tectonic stage during which chalcopyrite precipitated in veins crosscutting both pyrrhotite and pyrite-rich paragenesis.

Pyrrhotite in the $\mathrm{Cu}$-rich lenses is deformed and stretched along the $\mathrm{S}_{1}$ cleavage. Pyrite fills veins that crosscut pyrrhotite in the massive ore, and crystallizes in pressure shadows and along the $S_{1}$ cleavage in the disseminated ore. The pyrite veins are in turn crosscut by chalcopyrite forming veins that are parallel to the $S_{1}$ cleavage. Such a pattern indicates that the chalcopyrite parallel veins opened during a subsequent tectonic event with different stress directions as when the pyrite veins formed (Fig. 10ac). Hence the cleavage serves as a receptacle for chalcopyrite concentration in a late deformation event that causes dilation parallel to a pre-existing cleavage (Chauvet et al. 2019). The evidence clearly supports the pyrrhotite-rich mineralization as being overprinted and further remobilized by syn- to late-tectonic pyrite- and chalcopyrite-rich mineralization.

\section{Mineralogy of the sulphides}


Downloaded from http://sp.lyellcollection.org/ at Universite Nice Sophia Antipolis (ISTEX) on February 6, 2020

The massive sulphides are principally composed of pyrrhotite, sphalerite, galena and chalcopyrite, with lesser amounts of magnetite, chlorite, sericite and quartz. At the hand specimen-scale there is a marked variation in texture and mineralogy between the $\mathrm{Cu}$-rich and the $\mathrm{Zn}$-rich ores.

\section{The Zn-rich massive sulphide mineralization}

The massive ore within the $\mathrm{Zn}$-rich lens is composed of pyrrhotite together with lesser amounts of sphalerite, galena, chalcopyrite and arsenopyrite, which form a faint layering marked by alternation of pyrrhotite-rich and sphalerite-rich bands. Pyrrhotite is generally present as grains $<1 \mathrm{~mm}$ long stretched along the $S_{1}$ fabric. Grain boundaries with the other sulphide minerals are often irregular. Recrystallized equant grains of pyrrhotite showing triple junctions are locally present. Sphalerite occurs as subhedral or elliptical grains typically $<0.5 \mathrm{~mm}$ long. Galena is present as anhedral grains roughly $0.2 \mathrm{~mm}$ in length showing a spongy texture (i.e. full of micrometer-scale inclusions of other sulphides); the grains are aligned along the $S_{1}$ fabric and associated to sphalerite and pyrrhotite. Arsenopyrite occurs as individual euhedral crystals 0.1 to $0.2 \mathrm{~mm}$ in diameter. Chalcopyrite is present as elongate anhedral grains $<0.4 \mathrm{~mm}$ long.

With contents up to 90 vol.\%, pyrrhotite is the dominant sulphide in the $\mathrm{Zn}$-rich lens (Fig. $7 g, h$; Fig. $11 a, b)$. Its zinc content is high (300-6600 ppm) and copper is highly variable (average $700 \mathrm{ppm}$ ); the higher values can be due to minute inclusions of chalcopyrite (Table 1). Arsenic and cobalt have not been detected while tin and nickel contents are low ( $<100 \mathrm{ppm}$ owing to EPMA analyses). Pentlandite has not been observed. Its $\mathrm{XFeS}=0.92$ and its formula is close to $\mathrm{Fe}_{7} \mathrm{~S}_{8}$. Three trace elements have been detected in pyrrhotite with highly variable concentrations of cadmium (average $400 \mathrm{ppm}$ ), bismuth (average $200 \mathrm{ppm}$ ), and antimony (average $100 \mathrm{ppm}$ ).

Sphalerite is the second dominant sulphide in the $\mathrm{Zn}$-rich lens where it is concentrated along mmscale bands (Fig. 11b). Its iron content ranges from 5.77 to 7.09 wt\% (= XFeS 10-12 mole\%). Copper and cadmium contents are high, 600-800 ppm and 1000-1500 ppm respectively; some very high occurrences of copper values (4500 ppm) could be due to minute inclusions of chalcopyrite. Nickel and cobalt are low $(<100 \mathrm{ppm})$ as well as arsenic $(<300 \mathrm{ppm})$. Bismuth is highly variable (mean 400 ppm); the highest values (up to $1800 \mathrm{ppm}$ ) may be due to minute inclusions of bismuth.

Galena is less abundant than sphalerite to which it is generally associated (Fig. $7 g$; Fig. 11c). It is rich in zinc (1.35-1.45 wt\%) and iron (1.26-1.57 wt \%) and contains traces of copper (100-700 ppm), arsenic (600-700 ppm) and cadmium (800-1000 ppm).

Less abundant than sphalerite, chalcopyrite occurs as disseminated grains within pyrrhotite and has a homogenous composition. It may be rich in zinc or contain traces of bismuth, tin, cadmium, and arsenic. The high contents of zinc (up to $4200 \mathrm{ppm}$ ) probably result from subsurface inclusions of sphalerite. 
Downloaded from http://sp.lyellcollection.org/ at Universite Nice Sophia Antipolis (ISTEX) on February 6, 2020

Pyrite is rare and occurs as isolated grains within a matrix of pyrrhotite, sphalerite and galena. Most commonly pyrite forms the margins of carbonate veins where it replaces pyrrhotite. Porphyroblasts of pyrite, up to $1 \mathrm{~cm}$ in diameter, displaying asymmetric pressure shadows were also observed (Fig. 10d). Its zinc and arsenic contents range from 500 to $600 \mathrm{ppm}$, and from 300 to $800 \mathrm{ppm}$, respectively.

Arsenopyrite is the most abundant minor sulphide in the $\mathrm{Zn}$-rich lenses. It is enclosed within pyrrhotite and presents fragmented or corroded boundaries indicating a most likely early precipitation. As noted by Marcoux et al. (2008), independently from the grain size, arsenopyrite is As-rich (32-34 atom.\% As). It contains variable amounts of zinc (mean 2300 ppm), cobalt (mean 300 ppm), nickel (200-3600 ppm) and antimony (mean 1700 ppm), low amounts of cadmium (mean 100 ppm) but bismuth has not been detected.

Stannite was observed in the Zn-rich lens where it occurs as fine clusters within sphalerite (Fig. 11d). Cassiterite was reported from the Zn-rich ore by Barrakad et al. (1977).

\section{The Cu-rich massive sulphide mineralization}

Massive sulphides of the $\mathrm{Cu}$-rich lenses contain essentially pyrrhotite, chalcopyrite, pyrite, sphalerite, arsenopyrite and cobaltite. Native bismuth, Bi-rich sulphides and selenides are present as individual crystals or complex intergrowths within chalcopyrite and pyrrhotite. The associated non-sulphide minerals are chlorite, quartz, muscovite and Fe-rich carbonates. Pyrrhotite occurs as elongate grains, $1-5 \mathrm{~mm}$ long (Fig. $8 c, d$ ), exhibiting straight boundaries between crystals and $120^{\circ}$ triple junctions. It includes inclusions of chlorite sphalerite, cobaltite and arsenopyrite. When present, pyrite occurs within fractures and replaces pyrrhotite. The modal abundance of chalcopyrite reaches 35\% contrasting with its low abundance in the $\mathrm{Zn}$-rich lens $(<5 \%)$. Chalcopyrite occurs as patches invading pyrrhotite or most commonly as regular mm- to $\mathrm{cm}$-scale veins or fracture fillings in pyrrhotite and pyrite. Due to impinging growth of chalcopyrite into pyrrhotite and pyrite, inclusions of pyrrhotite and pyrite are common within and along the boundaries of chalcopyrite. Arsenopyrite is associated with chalcopyrite where it occurs as subhedral to irregular grains $<0.1 \mathrm{~mm}$ in diameter (Fig. $8 g$ ). Sphalerite occurs as irregular crystals $(<1 \mathrm{~mm})$ associated to arsenopyrite clusters or located at the boundaries of chalcopyrite.

Pyrrhotite is the dominant sulphide in the $\mathrm{Cu}$-rich lenses although its proportion is lower and its size is larger than in the $\mathrm{Zn}$-rich lens. Its $\mathrm{XFe}=0.92$ and its formula is close to $\mathrm{Fe}_{7} \mathrm{~S}_{8}$ (Table 1). It contains $\mathrm{Cu}$ (100-500 ppm) and Bi (mean 500 ppm) while its zinc content is low (mean 100 ppm). Arsenic and cobalt are present (mean 100 ppm) together with nickel (mean 300 ppm) and tin (mean 200 ppm). Cadmium and antimony contents are low ( $<200 \mathrm{ppm})$.

Sphalerite is a minor phase in the $\mathrm{Cu}$-rich lenses where it is associated with pyrrhotite. Its iron content ranges from 6.37 to 7.29 wt.\% (= XFeS $11-13$ mole\%). Copper and cadmium contents are very high, 
Downloaded from http://sp.lyellcollection.org/ at Universite Nice Sophia Antipolis (ISTEX) on February 6, 2020

ranging between $1800-8100 \mathrm{ppm}$ and $1300-3900 \mathrm{ppm}$ respectively. Bismuth is highly variable (mean $300 \mathrm{ppm}$ ) when compared with arsenic (mean $200 \mathrm{ppm}$ ) and cobalt (mean $300 \mathrm{ppm}$ ) while nickel is almost absent $(<100 \mathrm{ppm})$.

In the $\mathrm{Cu}$-rich lenses the galena is rare, it is fissured and always associated with carbonates.

Chalcopyrite is the most abundant sulphide after pyrrhotite and forms bands that cut across both pyrite and pyrrhotite (Fig. 10a-b; Fig. 11f). Chalcopyrite is the latest precipitated sulphide; its proportion can reach $20 \%$ and its composition is homogeneous. It is poor in zinc and nickel $(<100 \mathrm{ppm})$ and contains variable amounts of bismuth (mean $500 \mathrm{ppm}$ ), arsenic mean $300 \mathrm{ppm}$ ) and tin (mean $200 \mathrm{ppm}$ ), and traces of antimony and cadmium.

Pyrite is abundant and forms either veins or fractures crosscutting pyrrhotite or centimeter-scale patches within pyrrhotite (Fig. $8 e, f$ ). In both cases, the relationship between the two minerals is clear: pyrite replaces pyrrhotite. The replacement of pyrrhotite by pyrite, involving a decrease in volume, was accompanied by the deposition of other minerals, especially magnetite and siderite. Pyrite contains variable amounts of nickel (100-1500 ppm), copper (mean 300ppm), bismuth, cadmium, and cobalt (mean 200 ppm).

Arsenopyrite in the $\mathrm{Cu}$-lenses is generally associated with chalcopyrite. It is arsenic-rich (32-33 atom. $\%$ As) and contains high amounts of copper (250-9700 ppm) and variable amounts of cobalt (mean 200 ppm) and antimony (600-900 ppm). Zinc, nickel and cadmium contents are low (mean 100 ppm) and bismuth has not been detected.

Cobaltite is present in the $\mathrm{Cu}$ lenses as 0.025 to $0.25 \mathrm{~mm}$ wide crystals within and pyrrhotite (Fig. $11 e$ ) and as irregular crystals within chalcopyrite. It contains $2.36-2.48 \mathrm{wt} \%$ iron, up to $4 \%$ nickel and up to $900 \mathrm{ppm}$ copper. Small inclusions of cassiterite were also observed within pyrrhotite; it is fissural and associated with carbonates.

Native gold, native bismuth, Bi-rich sulphides and selenides are abundant as individual crystals or complex intergrowths within the $\mathrm{Cu}$-rich lenses. Some of the Bi-selenides and sulphides also contain silver and tellurium, and in rare places crystals up to c. $10 \mu \mathrm{m}$ of native electrum (Fig. 12). Native gold does not exceed $2.5 \mu \mathrm{m}$ in diameter and occurs as inclusions within pyrrhotite, chalcopyrite and cobaltite. Electrum is rarely intergranular but forms inclusions in all the sulphides of the Cu-rich lenses except pyrite (Fig. 12a-d). A Bi-Se association composed of small (15 to $30 \mu \mathrm{m})$ inclusions of laitakarite, $\mathrm{Bi}_{4}(\mathrm{Se}, \mathrm{S})_{3}$ and native bismuth within chalcopyrite was also described in some copper lenses by Marcoux et al. (2008) while small $(20 \mu \mathrm{m})$ inclusions of paraguanajuatite and bismuthinite (Bi2S3), electrum and mackinawite (FeS) were reported by Barrakad et al. (1977).

\section{Geochemistry}


Downloaded from http://sp.lyellcollection.org/ at Universite Nice Sophia Antipolis (ISTEX) on February 6, 2020

Among the drill cores intersecting the $\mathrm{Zn}$-rich and $\mathrm{Cu}$-rich lenses the drill core DF318 is representative of the mineralogy and textures of both ore types and allows comparison of the geochemistry of the $\mathrm{Zn}$ - and the $\mathrm{Cu}$-rich lenses (Table 2). The drill core intersects the $\mathrm{Zn}$-rich lens at a depth of $100 \mathrm{~m}$ and the $\mathrm{Cu}$-rich lenses at $200 \mathrm{~m}$ and $240 \mathrm{~m}$. The plots of Figure 13 show that elements such as lead, silver and arsenic are enriched in the Zn-rich lens (Fig. 13a, $b$, f), while cobalt and gold show higher concentrations in the $\mathrm{Cu}$-rich lenses (Fig. 13e, $g$ ). The elevated cobalt contents in the $\mathrm{Cu}$ rich lenses are attributed to the presence of cobaltite while the high contents of lead and arsenic are due to the presence of galena and arsenopyrite in the $\mathrm{Zn}$-rich lens. The high gold contents in the $\mathrm{Cu}$ rich lenses are mainly attributed to the presence of native gold and electrum while the high silver contents in the $\mathrm{Zn}$-rich lens may be due to high contents of silver in galena as described in the Tazakourt orebody where silver contents in galena reach $0.13 \mathrm{wt} \%$ (Ben Aissi 2008). Inclusions of silver or silver-bearing minerals have not been observed within galena in the Draa Sfar district (Barrakad et al. 1977; Marcoux et al. 2008).

\section{Discussion}

\section{Relationships between the Zn-rich and the Cu-rich mineralization}

In VMS deposits, the contents of trace elements in pyrite reflect the composition of the zone in which it crystallizes (Huston et al. 1995): it is $\mathrm{Cu}$-rich in the $\mathrm{Cu}$-zone and $\mathrm{Zn}$-rich in the $\mathrm{Pb}-\mathrm{Zn}$ zone, a fact that has been related to zone-refining processes within the massive sulphides (Elderidge et al. 1983). In VMS deposits, cobalt content in pyrite is higher in $\mathrm{Cu}$-rich zones than in $\mathrm{Zn}$-rich zones, a fact that is related to high cobalt concentration in high-temperature hydrothermal fluids (Huston et al. 1995 and references therein). Huston et al. (1995) noted also that arsenic (and gold) content of pyrite increases from the $\mathrm{Cu}$-rich to the $\mathrm{Zn}$-rich zones of VMS deposits but this pattern disappears in deposits that have undergone metamorphic recrystallization because these elements are expelled from recrystallized pyrite. At Sidi M'Barek, pyrite is rich in copper and cobalt in the Cu-rich lenses, whereas it is rich in zinc and arsenic in the Zn-rich lens. Thus, the copper and cobalt contents of pyrite may be consistent with the interpretation of Marcoux et al. (2008) who suggested that the Cu-zone might represent for the Draa Sfar ore deposit the upper part of a stockwork zone that has been strongly transposed by deformation. However the $\mathrm{Cu}$ lenses extend to the North of the $\mathrm{Zn}$-rich lens, which is dissimilar to the zoning commonly found in other VMS deposits, with $\mathrm{Cu}$-rich zones towards the central and lower parts of the masses, barren pyrite in the core and a $\mathrm{Zn}+\mathrm{Pb}$ enrichment towards the upper and lateral zones of the orebodies, (e.g., Large 1977; Lecolle 1977; Sato 1972; Sangster 1972). Moreover, a recent drill hole to the south of the Tensift River intercepted a Cu-rich zone within the $\mathrm{Pb}-\mathrm{Zn}$-rich lens.

The $\mathrm{Cu}-\mathrm{Au}-\mathrm{Bi}$ association and the high contents of gold in the $\mathrm{Cu}$-lenses at Sidi M'Barek contrast with the Bathrust mining camp, especially the Brunswick No 6 deposit where the gold content is higher in the $\mathrm{Zn}-\mathrm{Pb}$ zone than in the $\mathrm{Cu}$-zone. In this deposit, the main geochemical and mineralogical 
Downloaded from http://sp.lyellcollection.org/ at Universite Nice Sophia Antipolis (ISTEX) on February 6, 2020

differences observed between the $\mathrm{Pb}-\mathrm{Zn}$ zone and $\mathrm{Cu}$ zone were interpreted to have resulted from primary depositional features and from an almost coeval high-temperature zone refining process (Maclellan et al. 2006). Such an interpretation was supported by the $\square^{34} \mathrm{~S}$ values of the bulk sulphides, which are similar in the $\mathrm{Pb}-\mathrm{Zn}$ zone and the basal $\mathrm{Cu}$ zone. This is not the case at Sidi M'Barek where the sulphur isotopic signature of pyrite $(-2.5$ to $-0.8 \%)$ is different from that of pyrrhotite $(-6.4 \%$ to $-7.4 \%)$ and chalcopyrite ( -6.1 to $-5.2 \%$ ) indicating that distinct sources of sulphur were involved (Fig. 14a; Essaifi et al. 2019). In contrast the $\delta^{34} \mathrm{~S}$ value of pyrrhotite from the $\mathrm{Zn}$-rich lens (-7.2\%o) is similar to that of pyrrhotite from the $\mathrm{Cu}$-rich lenses indicating that sulphur in pyrrhotite was derived from the same sulphur source, and suggests a local remobilization of pyrrhotite.

The greater proportion of copper, together with gold, and cobalt, and the lower contents of zinc, lead and silver could be consistent with the interpretation that the main control of the formation of the $\mathrm{Cu}$ rich lenses was higher temperatures (Heinrich \& Eadington, 1986). Such an interpretation is however not supported by the zonation of the hydrothermal alteration, which is marked by a lateral change from a predominantly chlorite alteration in the footwall of the Tazakourt orebody to sericite alteration in the Sidi M'Barek deposit (Belkabir et al. 2008). The differences observed between $\mathrm{Cu}$-rich and $\mathrm{Cu}$ poor zones could be best accounted for by differences in the Se/S ratios of the hydrothermal fluids. Fluids in $\mathrm{Zn}$-rich zones have low Se/S ratios, typical of evolved seawater with minimal magmatic input, while fluids in the $\mathrm{Cu}$-rich zones have high $\mathrm{Se} / \mathrm{S}$ ratios, which is consistent with a significant magmatic component (Huston et al. 1995). The high Se/S ratios indicated by the abundance of the selenides in the $\mathrm{Cu}$-rich lenses and the sulphur isotopic ratios of pyrite, which are close to $0 \%$, are consistent with magmatic derivation, either via exsolution of magmatic fluids or leaching of igneous rocks.

The thin layering developed within the $\mathrm{Zn}$-rich lens by alternation of sphalerite-rich bands and pyrrhotite-rich bands may represent a primary depositional feature, but the absence of preserved primary textures within the orebodies (Moreno et al. 2008, Marcoux et al. 2008), and the fact that these bands are strictly parallel to the schistose fabric and developed in high strain zones indicate that they may have resulted from local segregation and redistribution of pyrrhotite during prograde metamorphism (cf. McQueen 1987). However, given the low ductility contrast between pyrrhotite, galena, sphalerite and chalcopyrite, the observed zonation and distribution of base and trace metals at Sidi M'Barek cannot be explained by mechanical remobilization only. Elongation of sphalerite, pyrrhotite, chalcopyrite, and galena along the $S_{1}$ cleavage in the $\mathrm{Zn}$-rich lens, and the formation of pressure shadows of quartz, muscovite, chalcopyrite, and pyrite around rigid objects in disseminated ore, are strong evidence for pressure solution in the orebodies and enclosing host rocks. Even if fluidassisted remobilization was active, metamorphic mobilization followed by transport, focusing and precipitation in the emplacement site should be involved because the lead isotope signatures recorded 
Downloaded from http://sp.lyellcollection.org/ at Universite Nice Sophia Antipolis (ISTEX) on February 6, 2020

at Draa Sfar are less radiogenic in the $\mathrm{Zn}$-rich lens than in the $\mathrm{Cu}$-rich lenses and track the existence of lead from two sources (Fig. 14b). A less radiogenic source (with ${ }^{206} \mathrm{~Pb} /{ }^{204} \mathrm{~Pb}$ close to 18.28) dominated in the $\mathrm{Zn}$-rich lens, and a more radiogenic source $\left({ }^{206} \mathrm{~Pb} /{ }^{204} \mathrm{~Pb} \sim 19.01\right)$ was predominant in the $\mathrm{Cu}$-rich lenses (Marcoux et al. 2008). The most radiogenic lead isotope signatures are recorded in the syn- to late-tectonic pyrite veins crosscutting pyrrhotite at Sidi M'Barek, and mark a contribution of radiogenic lead during the syn-metamorphic mineralization, coeval with low-grade metamorphism (Essaifi et al. 2019), while the less radiogenic $\mathrm{Pb}$ isotopic values are represented by the $\mathrm{Zn}$-rich ore of Tazakourt, and suggest a major contribution of volcanic rocks as source of metals (Marcoux et al. 2008; Bouabdellah et al. 2016). The other data points form a mixing trend suggesting that the advent of the $\mathrm{Cu}$-mineralization resulted in a radiogenic $\mathrm{Pb}$ component being added to the isotopically less radiogenic $\mathrm{Zn}$-rich mineralization. Hence the $\mathrm{Pb}$ isotopic data suggest a significant difference in age between the $\mathrm{Zn}-\mathrm{Pb}$ mineralization and the introduction of $\mathrm{Cu}-\mathrm{Au}$. This is consistent with the superimposed paragenetic successions observed at Sidi M'Barek, which point to a polyphase mineralization rather than a single mineralizing event.

\section{Genetic model}

The difference between the deformational features of the $\mathrm{Zn}$-rich lens and the $\mathrm{Cu}$-rich lenses most likely reflects different times of emplacement. The morphology of the Zn-mineralization, which is composed of one lens located near the boundary between the carbonaceous and the sandy metapelites, suggests an initially stratiform orebody and hence a synsedimentary deposition of the Znmineralization (Marcoux et al. 2008). Moreover the Zn-rich lens in the Tazakourt deposit is hosted by volcanic and volcaniclastic rocks suggesting an association with a synsedimentary volcanic activity (Marcoux et al. 2008; Belkabir et al. 2008). However, the morphology of the lens, which is elongated for almost $2 \mathrm{~km}$ horizontally and at least $1500 \mathrm{~m}$ vertically, shows important variations in thickness suggesting that ductile deformation has accentuated stretching and boudinage of a sheet-like original morphology of the lens.

Well-developed tectono-metamorphic fabrics characterize the $\mathrm{Zn}$-rich lens. It is a highly deformed lens showing mylonitic and recrystallization textures. In this lens most sulphides exhibit recrystallization and remobilization by pressure-solution. Pyrrhotite is stretched and flattened along the cleavage plane or exhibits annealing recrystallization textures. Grain flattening and elongation also characterize galena. Sphalerite is weakly flattened along the cleavage plane and pressure shadows are well developed around the grains. However strain-induced exsolution of chalcopyrite in sphalerite have not been observed. Arsenopyrite is present as euhedral grains showing well developed pressure shadows while chalcopyrite crystallizes in the pressure fringes. These features, which have been interpreted to result from fluid-state remobilization (Gilligan \& Marshall 1987; Park 1996; Marshall \& Spry 2000), indicate that these sulphide minerals are deformed and most likely their crystallization is pre-tectonic and pre-metamorphic. Hence the Zn-rich lens suffered considerable textural 
Downloaded from http://sp.lyellcollection.org/ at Universite Nice Sophia Antipolis (ISTEX) on February 6, 2020

modification during syn-metamorphic deformation. However, when present in the $\mathrm{Zn}$-rich lens, pyrite is secondary and postdates the pre-tectonic assemblage.

Morphology of the Cu-mineralization, which is composed of numerous vertical veins more or less continuous, suits that of a lode rather than that of a stratiform orebody. The mineralized $\mathrm{Cu}$-lenses show no mesoscopic deformation structures similar to those observed in the $\mathrm{Zn}$-rich lens, which suggest that they have escaped the ductile deformation that affected their host rocks. These lenses are characterized by a sigmoidal-like pull apart shape (Figs $4 \& 10 \mathrm{c}$ ), and by dilation and replacement textures leading to formation of a mineral banding with chalcopyrite-rich bands alternating with pyrite- and/or pyrrhotite-rich bands. A well-defined schistose fabric is lacking in the pyrite- and chalcopyrite-rich bands while in the pyrrhotite-rich bands, pyrrhotite is coarse-grained and elongated suggesting that it underwent recrystallization and ductile deformation. The similarity of the $\delta^{34} S$ values of pyrrhotite in the $\mathrm{Cu}$-rich lenses and the $\mathrm{Zn}$-rich lens indicates a common source of sulphur and suggests a remobilization of ductile sulphides at a larger scale (Gilligan \& Marshall 1987; Marshall et al. 2000).

The pyrrhotite-rich bands are crosscut by pyrite veins, which in turn are crosscut by chalcopyrite. When it occurs as disseminated minerals within carbonaceous beds, pyrite crystallizes in the pressure shadows around echinoderm clasts or as flattened crystals along the cleavage plane (Fig. 8h). As pyrite is normally more competent than the carbonate matrix, the absence of pressure fringes around pyrite indicates that pyrite is not a pre-tectonic mineral. On the contrary, this suggests that pyrite crystallized following the cleavage direction. The presence of pyrite porphyroblasts within deformed pyrrhotite in the $\mathrm{Zn}$-rich lens indicates that ductile deformation of pyrrhotite enhanced porphyroblastic growth of pyrite during greenschist metamorphism (Vokes 2000; Maclellan et al. 2006). Because the sulphur isotopic signature of pyrite is different from that of pyrrhotite, the growth of pyrite and the replacement of pyrrhotite by pyrite were assisted by an external source of sulphur. On the contrary, the similarity of the $\delta^{34} \mathrm{~S}$ values of pyrrhotite and chalcopyrite suggests an in-situ remobilization of ductile sulphides. Indeed, chalcopyrite fills extensional relays or pull-aparts related to a late stage of brittle-ductile deformation (Fig. 10c).

The relationships between the main sulphides and ductile deformation allowed us to distinguish an early mineralizing stage that is dominated by pyrrhotite, together with chalcopyrite, sphalerite and galena, accompanied by variable amounts of chlorite, sericite and quartz. A syn-tectonic stage is dominated by pyrite and precipitation of carbonates whereas a late- to post-tectonic stage is dominated by chalcopyrite accompanied by quartz- The presence of asymmetric pressure shadows around arsenopyrite and sphalerite in disseminated ore and the widespread deformation and shearing of the $\mathrm{Zn}$-rich lens indicates that the early mineralizing event is clearly pre- to syntectonic, and supports formation of the $\mathrm{Zn}$-rich precursor mineralization at and below the seafloor in an anoxic basin, during a transtentional deformation event (Belkabir et al. 2008; Moreno et al. 2008; Marcoux et 
Downloaded from http://sp.lyellcollection.org/ at Universite Nice Sophia Antipolis (ISTEX) on February 6, 2020

al. 2008). The widespread replacement of pyrrhotite by pyrite and the crystallization of pyrite in the pressure shadows around rigid objects, together with the presence of pyrite porphyroblasts within deformed pyrrhotite, indicate that this mineralizing event is syn- to late-tectonic and contemporaneous with transpression, basin closure and metamorphism. This transpressional event is characterized by formation of N-S sinistral shear zones and associated NE-SW striking $\mathrm{S}_{1}$ cleavage under the effects of a NW-SE directed shortening (Fig. 15a), which has been previously recognized as the major postVisean tectonometamorphic event at both the scale of Central Jebilet (Essaifi et al. 2001) and the Moroccan Meseta (Lagarde et al. 1990). During this event, the pre-existing Zn-rich lens and disseminated sulphides underwent ductile deformation, shearing and remobilization while an external sulphur source allowed deposition of pyrite within structurally controlled veins. A second event of compressional deformation is marked in the Draa Sfar district by an E-W striking $\mathrm{S}_{2}$ crenulation cleavage (Belkabir et al. 2008; Marcoux et al. 2008; Rziki 2012). During this N-S shortening event, dextral shearing re-used the previously formed shear zones and allowed sigmoidal extensional relays (pull aparts) to open along the pyrrhotite-rich lenses (Fig. 15b). During this stage chalcopyrite crystallized along parallel veins caused by dilation along the re-opened shear zones. The similarity of the sulphur isotopic signatures of chalcopyrite and pyrrhotite suggests an in situ remobilization of sulphur, while the lead isotopic signature of the $\mathrm{Cu}$-rich lenses, which is significantly more radiogenic than that of the Zn-rich mineralization, points out to the metals being inherited from the hosting black shales. Taken together, these isotopic data would rather indicate interplay between remobilization and mobilization processes during formation of the $\mathrm{Cu}$-rich lenses.

\section{Conclusion}

On the basis of metal contents, the Koudiat Sidi M'Barek deposit is composed of a Zn-rich lens and $\mathrm{Cu}$-rich lenses, and thus constitutes a representative example of the massive sulphide deposits of the Moroccan Meseta, which are composed of either $\mathrm{Cu}$-rich or $\mathrm{Zn}$-rich orebodies. The $\mathrm{Zn}$-rich lens is enriched in silver, lead and arsenic, whereas in the $\mathrm{Cu}$-zone, higher concentrations of cobalt and gold are exhibited. The Zn-rich mineralization forms a stratiform sheet-like lens that was dismembered by superimposed ductile and brittle Variscan deformation. This lens represents the northern prolongation of the Tazakourt deposit, which is associated with felsic volcanic and volcaniclastic rocks, and presents structural and textural features consistent with a VMS type precursor that was further deformed and remobilized by pressure solution during the post-Visean shortening. The Cu-rich mineralization forms several structurally controlled, foliation-parallel veins that display superimposed paragenetic successions and coupled dilation-replacement textures. A coarse grained pyrrhotite is crosscut and replaced by pyrite, which in turn is replaced by chalcopyrite. The $\mathrm{Cu}$-rich mineralized bodies were derived from syn- to post-tectonic mobilization of dispersed metals in the country rocks, probably interacting with metamorphic remobilization of pretectonic, massive and disseminated mineralization. The weight of evidence clearly supports Sidi M'Barek as being remobilized, 
Downloaded from http://sp.lyellcollection.org/ at Universite Nice Sophia Antipolis (ISTEX) on February 6, 2020

pretectonic $\mathrm{Zn}-\mathrm{Pb}$ systems that have been partially overprinted and further remobilized by syntectonic $\mathrm{Cu}-\mathrm{Au}$ systems.

\section{Acknowledgements}

Constructive comments by Saeed Alirezaei improved presentation of data and discussion. These comments are highly appreciated. We wish to thank K. Goodenough, P. Lusty and A. Lacinska from the BGS, A. Hamiane, M. Essaoudi and L. Maacha from Managem for discussions during the fieldtrips and the mine visits. This work received a financial support from the project URAC 43.

\section{References}

Aarab, E. \& Beauchamp, J. 1987. Le magmatisme carbonifère pré- orogénique des Jebilet centrales (Maroc). Précisions pétrographiques et sédimentaires, implications géodynamiques. Comptes Rendus de l'Académie des Sciences Paris, 304, 169-175.

Admou, S., Branquet, Y., Badra, L., Barbanson, L., Outhounjite, M., Khalifa, A., Zouhair, M., Maacha, L. 2018. The Hajjar Regional Transpressive Shear Zone (Guemassa Massif, Morocco): Consequences on the Deformation of the Base-Metal Massive Sulphide Ore. Minerals, 8, 435, doi:10.3390/min8100435

Barrakad, A., Huvelin, P., Laforêt, C., Perez, S., Permingeat, F. \& Picot, P. 1977. Minéraux de cobalt, d'étain, de bismuth, de sélénium, d'or et d'argent dans l'amas sulfuré à pyrrhotite de Sidi Embarek (Jebilet). Notes et Memoires du Service Géologique du Maroc, 37, 129-138.

Beauchamp, J. 1984. Le carbonifère inferieur des Jebilet et de l'Atlas de Marrakech (Maroc): migration et comblement d'un bassin marin. Bulletin de la Société Géologique de France, 7, 10251032.

Beauchamp, J. \& Izart, A. 1987. Early Carboniferous basins of the Atlas-Meseta domain (Morocco): Sedimentary model and geodynamic evolution. Geology, 15, 797-800.

Beauchamp, J., Izart, A. \& Piqué, A. 1991. Les bassins d'avant-pays de la chaîne hercynienne au Carbonifère inférieur. Canadian Journal of Earth Sciences, 28, 2024-2041.

Belkabir, A., Gibson, H. L., Marcoux, E., Lentz, D. \& Rziki, S. 2008. Geology and wall rock alteration at the Hercynian Draa Sfar $\mathrm{Zn}-\mathrm{Pb}-\mathrm{Cu}$ massive sulphide deposit, Morocco. Ore Geology Review, 33, 280-306.

Ben Aissi, L. 2008. Contribution à L'étude Gîtologique des Amas Sulfurés Polymétalliques de Draa Sfar et de Koudiat Aïcha: Comparaison avec les Gisements de Ben Slimane et de Kettara (Jebilet Centrales, Maroc Hercynien). PhD thesis, Université de Marrakech.

Ben Aissi, L. El Boukhari, A., Hibti, M., Elharfi, M., Maacha, L., Zinbi, Y. 2005. Alteration hydrothermale et deformation ductile des roches volcaniques acides associées au gisement sulfuré de Draa Sfar ( Jebilet Centrales, Maroc ). Estudios Geológicos, 61, 147-160.

Bernard, A.J., Maier, O.W., Mellal, A. 1988. Aperçu sur les amas sulfurés massifs des hercynides marocaines. Mineralium Deposita, 23, 104-114.

Bordonaro, M. 1983. Tectonique et pétrographie du district à pyrrhotite de Kettara (Paléozö̈que des Jebilet, Maroc). PhD thesis, Université de Strasbourg.

Bouabdellah, M., Hibti, M., Maacha, L., Zouhair, M. \& Velasco, F. 2016. Geologic, Hydrothermal, and geochemical relationships between bimodal magmatism and massive sulphide mineralization in the Central Jebilet-Guemassa province (Western Moroccan Hercynides). In Bouabdellah, M. \& Slack, 
Downloaded from http://sp.lyellcollection.org/ at Universite Nice Sophia Antipolis (ISTEX) on February 6, 2020

F.J. ( Eds). Mineral Deposits of North Africa. Springer International Publishing, Switzerland, 437459.

Chauvet A. 2019. Structural Control of Ore Deposits: The Role of Pre-Existing Structures on the Formation of Mineralised Vein Systems. Minerals, 9, 56; doi:10.3390/min9010056

Cumming, G. L. \& Richards, J. R. 1975. Ore lead isotope ratios in a continuously changing Earth. Earth and Planetary Science Letters, 28,155-171.

Delchini, S., Lahfid, A., Plunder, A. \& Michard, A. 2016. Applicability of the RSCM geothermometry approach in a complex tectono-metamorphic context: The Jebilet massif case study (Variscan Belt, Morocco). Lithos, 256-257, 1-12.

Delchini, S., Lahfid, A. et al. 2018. The geological evolution of the Variscan Jebilet Massif, Morocco, Inferred From New Structural and geochronological analyses. Tectonics, 37, 4470-4493.

Dostal, J., Keppie J.D., Hamilton M.A., Aarab E.M., Lefort J.P. \& Murphy, J.B. 2005. Crustal xenoliths in Triassic lamprophyre dykes in western Morocco: tectonic implications for the Rheic Ocean suture. Geological Magazine, 142, 159-172.

Eldridge, C.S., Barton, P.B. \& Ohmoto, H. 1983. Mineral textures and their bearing on formation of the Kuroko orebodies: Economic Geology, Monograph 5, 241-281.

Essaifi, A., Lagarde, J.L. \& Capdevila, R. 2001. Deformation and displacement from shear zone patterns in the Variscan upper crust, Jebilet, Morocco. Journal of African Earth Sciences, 32, 335350 .

Essaifi, A., Potrel, A., Capdevila, R. \& Lagarde, J.L. 2003. Datation U-Pb : age de mise en place du magmatisme bimodal des Jebilet centrales (chaine Varisque, Maroc). Implications géodynamiques. Comptes Rendus Geosciences. 335, 193-203.

Essaifi, A. \& Hibti, M. 2008. The hydrothermal system of Central Jebilet (Variscan Belt, Morocco): A genetic association between bimodal plutonism and massive sulphide deposits. Journal of African Earth Sciences, 50, 188-203.

Essaifi, A., Samson, S. \& Goodenough, K. 2014. Geochemical and Sr-Nd isotopic constraints on the petrogenesis and geodynamic significance of the Jebilet magmatism (Variscan Belt, Morocco). Geological Magazine, 151, 666-691.

Essaifi, A. Goodenough, K., Tornos, F., Outigua, A., Ouadjou, A. \& Maacha, L.. 2019. The Moroccan Massive Sulphide Deposits: Evidence for a Polyphase Mineralization. Minerals, 9, 156, https://www.mdpi.com/2075-163X/9/3/156/pdf

Franklin, J.M., Sangster, D.F. \& Lydon, J.W. 1981. Volcanogenic massive sulphide deposits. Economic Geology, 75 $^{\text {th }}$ Anniversary volume, 485-627.

Gilligan, L.B. \& Marshall, B. 1987. Textural evidence for remobilization in metamorphic environments. Ore Geology Review, 2, 205-229.

Graham, J.R. 1982a. Wave-Dominated Shallow-Marine Sediments in the Lower Carboniferous of Morocco. Journal of Sedimentary Petrology, 52, 1271-1276.

Graham, J.R. 1982b. Transition from basin-plain to shelf deposits in the Carboniferous flysch of Southern Morocco. Sedimentary Geology, 33, 173-193. 
Downloaded from http://sp.lyellcollection.org/ at Universite Nice Sophia Antipolis (ISTEX) on February 6, 2020

Heinrich, C.A. \& Eadington, P.J. 1986. Thermodynamic predictions of the hydrothermal chemistry of arsenic, and their significance for the paragenetic sequence of some cassiterite-arsenopyrite-base metal sulfide deposits. Economic Geology, 81, 511-529.

Hibti, M. 2001. Les amas sulfurés des Guemassa et des Jebilet (Meseta Sud-Occidentale, Maroc) : Témoins de l'hydrothermalisme précoce dans le bassin mesetien. $\mathrm{PhD}$ thesis, Marrakech University.

Hoepffner, C., Soulaimani, A. \& Piqué, A. 2005. The Moroccan Hercynides. Journal of African Earth Sciences, 43, 144-165.

Huon, S., Piqué, A. \& Clauer, N. 1987. Etude de l'orogenèse hercynienne au Maroc par la datation $\mathrm{K} / \mathrm{Ar}$ de l'évolution métamorphique de schistes ardoisiers. Sciences Géologiques Bulletin Strasbourg, 40, 273-284.

Huston, D.L., Sie, S.H., Suter, G.F., Cooke, D.R. \& Both, R.A. 1995. Trace elements in sulphide minerals from Eastern Australia volcanic-hosted massive sulphide deposits-Part I: Proton microprobe analyses of pyrite, chalcopyrite, and sphalerite, and Part II: Selenium levels in pyrite: Comparison with $\delta^{34} \mathrm{~S}$ values and implications for the source of sulphur in volcanogenic hydrothermal systems. Economic Geology, 90, 1167-1196.

Huvelin, P. 1977. Etude géologique et gîtologique du Massif hercynien des Jebilet (Maroc occidental). Notes et Memoires du Service Géologique du Maroc, 232 bis, 1-307.

Izart, A., Beauchamp, J., Vachard, D., Tourani, A.I. \& Essamani, M. 1997. Stratigraphie séquentielle du Carbonifère inférieur du Haut Atlas central et des Jebilet (Maroc): Un exemple de bassins de turbidites controlés par la tectonique. Journal of African Earth Sciences, 24, 445-454.

Lagarde, J.L. 1989. Granites tardi-carbonifères et déformation crustale: l'exemple de la meseta marocaine. $\mathrm{PhD}$ thesis, Rennes I University.

Lagarde, J.L. \& Choukroune, P. 1982. Cisaillement ductile et granitoïdes syntectoniques: l'exemple du massif hercynien des Jebilet (Maroc). Bulletin de la Société Géologique de France, 7, 299-307.

Lagarde, J.L., Aït omar, S. \& Roddaz, B. 1990. Structural characteristics of syntectonic plutons with special reference to late carboniferous plutons from Morocco. Journal of Structural Geology, 12, $805-21$.

Large, R.R. 1992. Australian volcanic-hosted massive sulphide deposits: features, styles, and genetic models. Economic. Geology, 87, 471-510

Le Corre, C. \& Bouloton, J. 1987. Un modèle de "structure en fleur" associant décrochement et convergence: les Jebilet centro-occidentales (Maroc hercynien). Comptes Rendus de l'Académie des Sciences Paris, 304, 751-754.

Le Corre, C. \& Saquaque, A. 1987. Comportement d'un système pluton-encaissant dans un champ de déformation régional: le granite de Bramram (Jebilet, Maroc hercynien). Bulletin de la Société Géologique de France, 4, 665-73.

Lotfi, F., Belkabir, A., Brown, A.C., Marcoux, E., Brunet, S. \& Maacha, L. 2008. Geology and mineralogy of the Hercynian Koudiat Aïcha polymetallic ( $\mathrm{Zn}, \mathrm{Pb}, \mathrm{Cu}$ ) massive sulfide deposit, central Jebilet, Morocco. Exploration and Mining Geology, 14, 145-162.

Lotfi, F., Belkabir, A., Brunet, S., Brown, A. C. \& Marcoux, E. 2010. Lithogeochemical, mineralogical analyses and oxygen-hydrogen isotopes of the Hercynian Koudiat Aicha massive sulphide deposit, Morocco. Journal of African Earth Sciences, 56, 150-166. 
Downloaded from http://sp.lyellcollection.org/ at Universite Nice Sophia Antipolis (ISTEX) on February 6, 2020

Lusty, P.A.J., Goodenough, K.M., Essaifi, A. \& Maacha, L. 2015. Developing the lithotectonic framework and model for sulphide mineralization in the Jebilet Massif, Morocco: implications for regional exploration. In: André-Mayer, A.S., Cathelineau, M., Muchez, P.h., Pirard, E. \& Sindern, S. (eds). Mineral Resources in a Sustainable World, Proceedings of the $13^{\text {th }}$ Biennial SGA Meeting, Nancy, France, 24-27 August 2015, Society for Geology Applied to Mineral Deposits (SGA): Genéve, Switzerland, 1635-1638.

Maacha, L., Jaffal, M., Jarni, A., Kchikach, A., Mouguina, E., Zouhair, M., Ennaciri A. \& Saddiqi O. 2017. A contribution of airborne magnetic, gamma ray spectrometric data in understanding the structure of the Central Jebilet Hercynian massif and implications for mining. Journal of African Earth Sciences, 134, 389- 403

MacLellan, K.L., Lentz, D.R. \& McClenaghan, S.H. 2006. Petrology, geochemistry, and genesis of the copper zone at the Brunswick No. 6 volcanogenic massive sulfide deposit, Bathurst Mining Camp, New Brunswick, Canada. Exploration and Mining Geology, 15, 53-75.

Marcoux, E. 1998. Lead isotope systematics of the giant massive sulphide deposits in the Iberian Pyrite Belt. Mineralium Deposita, 33, 45-58

Marcoux, E., Belkabir, A., Gibson, H. L., Lentz, D. \& Ruffet, G. 2008. Draa Sfar, Morocco: A Visean (331 Ma) pyrrhotite-rich, polymetallic volcanogenic massive sulphide deposit in a Hercynian sediment-dominant terrane. Ore Geology Review, 33, 307-328.

Marshall, B. \& Spry, P. 2000. Discriminating between regional metamorphic remobilization and syntectonic emplacement in the genesis of massive sulphide ores. Reviews in Economic Geology, 11, $39-80$.

Marshall, B., Vokes, F.M. \& Larocque, A.C.L. 2000. Regional metamorphic remobilization: Upgrading and formation of ore deposits. Reviews in Economic Geology, 11, 19-38.

Mayol, S. \& Muller, J. 1985. Mise en évidence d'une unité allochtone hercynienne précoce (anteschisteuse) dans les Jebilet occidentales (Maroc). Etude de structuration de la zone de contact. Comp. Rendus Acad. Sci. Paris, 300, 369-372.

McQueen, K. G. 1987, Deformation and remobilization in some western Australian nickel ores. Ore Geology Review, 2, 266-286.

Michard, A., Soulaimani, A., Hoepffner, C., Ouanaimi, H., Baidder, L., Rjimati, E.C. \& Saddiqi, O. 2010. The south-Western branch of the Variscan Belt: evidence from Morocco. Tectonophysics, 492 , $1-24$.

Moreno, C., Saez, R., Gonzalez, F., Almodovar, G., Tosano, M., Playford, G., Alansari, A., Rziki, S. \& Bajddi, A. 2008. Age and depositional environment of the Draa Sfar massive sulphide deposit, Morocco. Mineralium Deposita, 43, 891-911.

Mrini, Z., Rafi, A., Duthou, J. L. \& Vidal, P. 1992. Chronologie Rb-Sr des granitoïdes hercyniens du Maroc: conséquences. Bulletin de la Société Géologique de France, 163, 281-291.

N'diaye, I. Essaifi, A., Dubois, M., Lacroix, B., Goodenough, K.M. \& Maacha, L. 2016. Fluid flow and polymetallic sulfide mineralization in the Kettara shear zone (Jebilet Massif, Variscan Belt, Morocco). Journal of African earth Sciences, 119, 17-37.

Oummouch, A. Essaifi, A., Zayane, R., Maddi, A., Zouhair, M. \& Maacha, L. 2017. Geology and metallogenesis of the sediment-hosted $\mathrm{Cu}-\mathrm{Ag}$ deposit of Tizert (Igherm inlier, Anti-Atlas Copperbelt, Morocco). Geofluids, https://doi.org/10.1155/2017/7508484 
Downloaded from http://sp.lyellcollection.org/ at Universite Nice Sophia Antipolis (ISTEX) on February 6, 2020

Park, A.F. 1996, Structural evolution of sulphide tectonites and their host rocks, Stratmat mine, New Brunswick. Canadian Journal of Earth Sciences, 33, 472-492.

Piqué, A. \& Michard, A. 1989. Moroccan hercynides: a synopsis. The Palaeozoic sedimentary and tectonic evolution at the northern margin of West Africa. American Journal of Science, 289, 286-330.

Piqué, A., Jeannette, D. \& Michard, A. 1980. The Western Meseta shear zone, a major and permanent feature of the Hercynian belt in Morocco. Journal of Structural Geology, 2, 55-61.

Rziki, S. 2012. Le gisement polymétallique de Draa Sfar: compilation et modélisation tridimentionnelle, géologique, géophysique et perspectives de développement (Massif Hercynien des Jebilet Centrales, Maroc). PhD thesis, Marrakech University.

Robert, F. \& Brown, A.C. 1986. Archean gold-bearing quartz veins at the Sigma mine, Abitibi greenstone belt, Quebec. Part I. Geologic relations and formation of the vein system. Economic Geology, 81, 578-592.

Sangster, D.F. 1972. Precambrian volcanogenic massive sulphide deposits in Canada. A review. Geological Survey of Canada Paper, 72-22.

Sato, T. 1972. Behaviours of ore-forming solutions in seawater. Mining Geology, 22, 31-42.

Stacey, J. S. \& Kramers, J. C. 1975. Approximation of terrestrial lead isotope evolution by a twostage model. Earth and Planetary Science Letters, 26, 207-221

Tourigny, G. Doucet, D. \& Bourget, A. 1993. Geology of the Bousquet 2 Mine: An example of a deformed, gold-bearing, polymetallic sulfide deposit. Economic Geology, 88, 1578-1597.

Vokes, F.M. 2000, Ore and metamorphism: Introduction and historical perspectives: Reviews in Economic Geology, 11, 1-18.

Zartman, R. E. \& Doe, B. R. 1981. Plumbotectonics-the model. Tectonophysics, 75, 35-162

Zouhry, S. 1999. Etude métallogénique d'un amas sulfuré viséen à Zn-Pb-Cu: Cas de Hajjar, Guemassa, Maroc. PhD thesis, École Polytechnique de Montréal.

\section{Figure Captions}

Fig. 1. The geological map of the Jebilet massif showing the location of Draa Sfar, Kettara and Koudiat Aicha massive sulphide deposits (modified from Huvelin, 1977). Inset shows the Jebilet massif in the frame of the Variscan outcrops of Morocco (in brown). EM: Eastern Meseta, WM: Western Meseta.

Fig. 2. Geological setting of the Central Jebilet Unit showing the schistose pelite of Sarhlef series, the outcrops of the magmatic rocks and the general distribution of the massive sulphide ore deposits (modified after Huvelin, 1977). The white color represents undifferentiated post-Paleozoic sedimentary units. Location of figure 3 is indicated.

Fig. 3. Geological map of the Draa Sfar mine area showing the surface projection of Koudiat (Kt.) Tazakourt and Koudiat Sidi M'Barek massive sulphide ore bodies, the host rocks and the selected drill holes illustrated in figures 5, 6 and 13. Location of figure 4 is indicated. 
Downloaded from http://sp.lyellcollection.org/ at Universite Nice Sophia Antipolis (ISTEX) on February 6, 2020

Fig. 4. Structural map of the Koudiat Sidi M'barek (underground mapping of level $-75 \mathrm{~m}$ supplemented by interpretation of drill cores). (a) stereonet showing equal area, lower hemisphere projection of the $S_{1}$ cleavage. (b) orientation of the fault planes measured in the mine level $-75 \mathrm{~m}$.

Fig. 5. East-west borehole sections at Koudiat Sidi M'Barek, drawn from detailed logging of the DS170, DS173, DS175 and DS223 drill cores shown in figure 3.

Fig. 6. East-west vertical cross sections across the zinc- and copper rich-lenses.

Fig. 7. The main features of the zinc-rich lens illustrated by drill core photographs and photomicrographs in transmitted and reflected light. (a) Banded ore with alternation of pyrrhotite-rich and sphalerite-rich bands. (b) Massive pyrrhotite with folded inclusions of metapelites (HR). (c-d) Disseminated Zn-rich ore showing pyrrhotite (Po) elongated along the $S_{1}$ cleavage while pressure shadows are developed around arsenopyrite (Apy); the main non-metallic minerals are chlorite (Chl), sericite (Ser) and quartz (Qtz); (c) reflected light, (d) transmitted light. (e-f) Pressure shadows developed around weakly flattened sphalerite (Sp); (e) reflected light, (f) transmitted light. (g-h) Znrich massive ore with the main sulphides elongated along the $S_{1}$ cleavage (Ga: Galena, Ccp: chalcopyrite); reflected light, PPL (g) and XPL (h).

Fig. 8. The main features of the copper-rich lenses illustrated by underground photographs and photomicrographs. (a) Photograph in the underground gallery showing unconformity between the $S_{1}$ cleavage in the metapelites (HR) and the extremity of a copper-rich lens composed of quartz (Qtz) and disseminated pyrrhotite (Po) and chalcopyrite. (b) Sample showing alternation of pyrrhotite-rich and chalcopyrite-rich bands. (c-d) Coarse-grained massive pyrrhotite showing triple junctions. Reflected light, XPL. (e) Pyrite (Py) and carbonate (Cb) infilling veins crossing massive pyrrhotite. (f) Chalcopyrite (Ccp) crosscutting pyrrhotite, pyrite and magnetite (Mag), and crosscut by a late carbonate vein. (g) Dissemination of arsenopyrite (Apy) and sphalerite (Sp), together with inclusions of pyrrhotite (Po) and metapelites (HR) in the chalcopyrite-rich band. (h) Syntectonic pyrite crystallizing along the $S_{1}$ cleavage marked by flattening of chlorite, sericite and quartz in a sample from the metapelites. Reflected light, PPL (e-h).

Fig. 9. Paragenetic successions of the mineralization at Koudiat Sidi M'barek.

Fig. 10. Photograph (a) and sketch (b) of the massive ore in the Cu-rich lenses showing the superimposition of pyrrhotite (Po), pyrite (Py) and chalcopyrite (Ccp). (c) Extensional relay filled by chalcopyrite and quartz. (d) Pyrite porphyroblast within pyrrhotite.

Fig. 11. Representative plane-polarised photomicrographs of the $\mathrm{Zn}$-rich and the $\mathrm{Cu}$-rich lenses. (a) Massive pyrrhotite with chalcopyrite and sphalerite in the Zn-rich lens. (b) Banding in the Zn-rich lens marked by pyrrhotite-rich and sphalerite-rich bands parallel to the $S_{1}$ tectonic cleavage. (c) Pyrrhotite (Po), sphalerite (Sp), galena (Gn), Chalcopyrite (Ccp) and inclusions of metapeltes (HR) flattened along the $S_{1}$ cleavage in the Zn-rich lens. (d) Inclusions of stannite within sphalerite in the Zn-rich lens. (e) Cobaltite within pyrrhotite in a $\mathrm{Cu}$-rich lens. (f) Chalcopyrite replacing pyrrhotite in a Cu-rich lens.

Fig. 12. Scanning Electron Microscope photographs showing native gold, electrum and bismuth inclusions within sulphides in the Cu-rich lenses. Native gold within pyrrhotite (a-b), cobaltite (c), and chalcopyrite (d). Electrum within chalcopyrite (e), pyrrhotite (f), sphalerite (g), arsenopyrite (h), cobaltite (i), and between pyrrhotite and cobaltite (j). po: pyrrhotite, Ccp: chalcopyrite, Apy: arsenopyrite.

Fig. 13. $\mathrm{Zn}, \mathrm{Pb}, \mathrm{Cu}, \mathrm{Ag}, \mathrm{Co}$, As and $\mathrm{Fe}$ element distribution in the $\mathrm{Zn}$-rich lens and the copper-rich lens in the DF 318 drill core, showing high contents of $\mathrm{Zn}, \mathrm{Pb}, \mathrm{Ag}$ and $\mathrm{As}$ in the $\mathrm{Zn}$-rich lens and low contents in the $\mathrm{Cu}$-rich lenses $(\mathbf{a}, \mathbf{b}, \mathbf{d}, \mathbf{f}) . \mathrm{Cu}, \mathrm{Co}$ and $\mathrm{Au}$ contents are high in the $\mathrm{Cu}$-rich and low in the Zn-rich lens (c, e, g). 
Downloaded from http://sp.lyellcollection.org/ at Universite Nice Sophia Antipolis (ISTEX) on February 6, 2020

Figure 14. Lead and sulphur isotopic compositions of the Draa Sfar ores (data from Marcoux et al. 2008; Essaifi et al. 2019). The lead isotopic compositions of the IPB VMS deposits (Blue field; Marcoux 1998) are also shown for comparison. S\&K: average growth curve of Stacey and Kramers (1975), C\&R: upper crust growth curve of Cumming and Richards (1975). Evolution curves for Upper Crust and Orogene (Zartman \& Doe 1981) are shown for reference.

Fig. 15. Two stage tectonic model for the formation of the $\mathrm{Cu}$-rich lenses of Sidi M'Barek.

(a) Stage 1, NW-SE shortening generating the $\mathrm{S}_{1}$ cleavage, remobilization of pyrrhotite-rich mineralization and deposition of pyrite within syntectonic veins associated to N-S left lateral shear zones.

(b) Stage 2, Reopening of the shear zones by right lateral shearing during a subsequent N-S shortening generating the $\mathrm{S}_{2}$ crenulation cleavage and deposition of chalcopyrite. 
Downloaded from http://sp.lyellcollection.org/ at Universite Nice Sophia Antipolis (ISTEX) on February 6, 2020

Table 1. Electron microprobe analysis of sulphide minerals of Koudiat Sidi M'Barek

\section{Pyrrhotite}

\begin{tabular}{|c|c|c|c|c|c|c|c|c|c|c|c|}
\hline & $\begin{array}{l}\text { Zn- } \\
\text { rich } \\
\text { lens } \\
\text { DF311- } \\
122\end{array}$ & $\begin{array}{l}\text { Zn- } \\
\text { rich } \\
\text { lens } \\
\text { DF311- } \\
122 \\
\end{array}$ & $\begin{array}{l}\text { Zn- } \\
\text { rich } \\
\text { lens } \\
\text { DF311- } \\
122 \\
\end{array}$ & $\begin{array}{l}\text { Zn- } \\
\text { rich } \\
\text { lens } \\
\text { DF276- } \\
67 \\
\end{array}$ & $\begin{array}{l}\text { Zn- } \\
\text { rich } \\
\text { lens } \\
\text { DF276- } \\
67\end{array}$ & $\begin{array}{l}\text { Cu- } \\
\text { rich } \\
\text { lens } \\
\text { DS161- } \\
90.5\end{array}$ & $\begin{array}{l}\mathrm{Cu}- \\
\text { rich } \\
\text { lens } \\
\text { DS161- } \\
90.5\end{array}$ & $\begin{array}{l}\text { Cu-rich } \\
\text { lens } \\
\text { L2-90- } \\
\text { Cpy-Py }\end{array}$ & $\begin{array}{l}\text { Cu-rich } \\
\text { lens } \\
\text { L2-90- } \\
\text { Cpy-Py }\end{array}$ & $\begin{array}{l}\text { Cu-rich } \\
\text { lens } \\
\text { L2-90- } \\
\text { Cpy-Py }\end{array}$ & $\begin{array}{l}\text { Cu-rich } \\
\text { lens } \\
\text { L2-90- } \\
\text { Cpy-Py }\end{array}$ \\
\hline$S$ & 39.84 & 39.34 & 39.34 & 39.58 & 39.71 & 39.18 & 39.43 & 39.13 & 39.59 & 39.65 & 39.55 \\
\hline $\mathrm{Fe}$ & 58.27 & 57.30 & 57.75 & 59.51 & 59.55 & 58.70 & 58.60 & 58.45 & 58.02 & 58.08 & 57.86 \\
\hline As & - & - & - & - & - & 0.02 & - & 0.02 & - & & 0.03 \\
\hline Co & - & - & - & - & - & 0.03 & 0.03 & - & & - & 0.01 \\
\hline $\mathrm{Cu}$ & - & 0.16 & 0.20 & 0.01 & - & 0.01 & 0.01 & 0.05 & 0.0 & 0.01 & 0.02 \\
\hline $\mathrm{Zn}$ & 0.44 & 0.06 & 0.66 & 0.05 & 0.03 & 0.01 & - & 0.01 & & 0.02 & - \\
\hline $\mathrm{Bi}$ & - & 0.06 & 0.02 & 0.04 & - & - & - & 0.13 & & - & 0.15 \\
\hline $\mathrm{Ni}$ & - & 0.01 & - & 0.01 & - & 0.04 & 0.05 & & 0.01 & 0.03 & 0.03 \\
\hline $\mathrm{Cd}$ & - & 0.07 & 0.03 & - & 0.08 & - & & 1 & - & 0.02 & - \\
\hline Sn & 0.01 & 0.01 & - & 0.01 & - & - & & 0.04 & 0.02 & 0.02 & 0.02 \\
\hline $\begin{array}{l}\text { Sb } \\
\text { Total }\end{array}$ & - & 0.01 & 0.05 & - & - & - & & 0.01 & - & - & 0.02 \\
\hline wt.\% & 98.56 & 97.02 & 98.05 & 99.21 & 99.36 & 97.99 & 98.13 & 97.84 & 97.66 & 97.82 & 97.69 \\
\hline S cat & 54.20 & 54.35 & 53.93 & 53.64 & 53.71 & 53.72 & 53.92 & 53.79 & 54.29 & 54.29 & 54.30 \\
\hline Fe cat & 45.50 & 45.44 & 45.45 & 46.30 & 46.24 & 46.20 & 46.00 & 46.12 & 45.68 & 45.66 & 45.60 \\
\hline XFeS & 0.91 & 0.91 & 0.91 & 0.93 & 0.92 & 0.92 & 0.92 & 0.92 & 0.91 & 0.91 & 0.91 \\
\hline
\end{tabular}

\section{Sphalerite}

\begin{tabular}{|c|c|c|c|c|c|c|c|c|c|c|c|c|}
\hline $\begin{array}{l}\mathrm{Zn-} \\
\text { rich } \\
\text { lens } \\
\text { DF311 } \\
-122\end{array}$ & $\begin{array}{l}\mathrm{Zn}- \\
\text { rich } \\
\text { lens } \\
\text { DF311 } \\
-122\end{array}$ & $\begin{array}{l}\text { Zn- } \\
\text { rich } \\
\text { lens } \\
\text { DF311 } \\
-122\end{array}$ & $\begin{array}{l}\mathrm{Zn-} \\
\text { rich } \\
\text { lens }\end{array}$ & $\begin{array}{l}\text { Zn- } \\
\text { rich } \\
\text { lens }\end{array}$ & $\begin{array}{l}\text { Zn- } \\
\text { rich } \\
\text { lens }\end{array}$ & $\begin{array}{l}\text { Zn- } \\
\text { rich } \\
\text { lens } \\
\text { DF276 } \\
-67\end{array}$ & $\begin{array}{l}\mathrm{Cu}- \\
\text { rich } \\
\text { lens } \\
\text { DS161 } \\
-90.5\end{array}$ & $\begin{array}{l}\mathrm{Cu}- \\
\text { rich } \\
\text { lens } \\
\text { DS161 } \\
-90.5\end{array}$ & $\begin{array}{l}\mathrm{Cu}- \\
\text { rich } \\
\text { lens } \\
\text { L2-90- } \\
\text { Cpy- } \\
\mathrm{Py}\end{array}$ & $\begin{array}{l}\mathrm{Cu}- \\
\text { rich } \\
\text { lens } \\
\text { L2-90- } \\
\text { Cpy- } \\
\mathrm{Py}\end{array}$ & $\begin{array}{l}\mathrm{Cu}- \\
\text { rich } \\
\text { lens } \\
\text { L2-90- } \\
\text { Cpy- } \\
\text { Py }\end{array}$ & $\begin{array}{l}\mathrm{Cu}- \\
\text { rich } \\
\text { lens } \\
\text { L2-90- } \\
\text { Cpy- } \\
\text { Py }\end{array}$ \\
\hline 33.1 & 33.1 & 33.0 & 33.4 & 32.8 & 33.0 & 32.3 & 33.2 & 33.3 & 33.3 & 32.7 & 33.1 & 32.9 \\
\hline 7 & 8 & 4 & 4 & 2 & 2 & 7 & 2 & 0 & 0 & 0 & 2 & 4 \\
\hline 6.65 & 6.70 & 6.95 & 6.71 & 6.68 & 5.77 & 7.09 & 6.37 & 6.49 & 6.66 & 7.29 & 7.07 & 7.00 \\
\hline 0.03 & 0.01 & - & 0.01 & - & - & 0.03 & 0.09 & - & - & - & 0.04 & - \\
\hline - & - & - & 0.01 & - & - & 0.01 & 0.04 & 0.05 & 0.02 & - & 0.01 & 0.03 \\
\hline 0.06 & 0.07 & 0.08 & 0.06 & 0.07 & 0.07 & 0.45 & 0.56 & 0.66 & 0.25 & 0.81 & 0.18 & 0.30 \\
\hline 59.5 & 59.6 & 59.7 & 59.8 & 60.6 & 61.0 & 59.2 & 59.2 & 59.7 & 60.1 & 58.5 & 59.6 & 59.3 \\
\hline 6 & 5 & 5 & 9 & 6 & 4 & 0 & 2 & 4 & 4 & 1 & 9 & 4 \\
\hline 0.10 & 0.10 & 0.13 & 0.13 & 0.12 & 0.15 & 0.11 & 0.39 & 0.29 & 0.13 & 0.15 & 0.22 & 0.15 \\
\hline 0.01 & - & - & - & - & - & 0.01 & - & 0.01 & - & - & - & - \\
\hline- & 0.18 & 0.08 & - & - & - & - & - & - & - & 0.12 & 0.04 & 0.02 \\
\hline 99.5 & 99.8 & 100. & 100. & 100. & 100. & 99.2 & 99.8 & 100. & 100. & 99.5 & 100. & 99.7 \\
\hline 8 & 8 & 03 & 25 & 34 & 03 & 6 & 9 & 53 & 51 & 8 & 37 & 8 \\
\hline 11.5 & 11.5 & 12.0 & 11.5 & 11.5 & & 12.3 & 11.0 & 11.1 & 11.4 & 12.6 & 12.1 & 12.1 \\
\hline 3 & 9 & 2 & 4 & 3 & 9.97 & 6 & 2 & 6 & 5 & 6 & 8 & 3 \\
\hline
\end{tabular}


Downloaded from http://sp.lyellcollection.org/ at Universite Nice Sophia Antipolis (ISTEX) on February 6, 2020

\section{Chalcopyrite}

\begin{tabular}{|c|c|c|c|c|c|c|c|c|c|c|c|c|c|}
\hline & $\begin{array}{l}\text { Zn- } \\
\text { rich } \\
\text { lens } \\
\text { DF311 } \\
-122\end{array}$ & $\begin{array}{l}\text { Zn- } \\
\text { rich } \\
\text { lens } \\
\text { DF311 } \\
-122\end{array}$ & $\begin{array}{l}\text { Zn- } \\
\text { rich } \\
\text { lens }\end{array}$ & $\begin{array}{l}\mathrm{Zn-} \\
\text { rich } \\
\text { lens } \\
\text { DF311 } \\
-122 \\
\end{array}$ & $\begin{array}{l}\mathrm{Zn-} \\
\text { rich } \\
\text { lens } \\
\text { DF276 } \\
-67\end{array}$ & $\begin{array}{l}\text { Cu- } \\
\text { rich } \\
\text { lens } \\
\text { DS161 } \\
-90.5\end{array}$ & $\begin{array}{l}\text { Cu- } \\
\text { rich } \\
\text { lens } \\
\text { DS161 } \\
-90.5\end{array}$ & $\begin{array}{l}\text { Cu- } \\
\text { rich } \\
\text { lens } \\
\text { DS170 } \\
- \text { E7 }\end{array}$ & $\begin{array}{l}\text { Cu- } \\
\text { rich } \\
\text { lens } \\
\text { DS170 } \\
\text {-E7 }\end{array}$ & $\begin{array}{l}\mathrm{Cu}- \\
\text { rich } \\
\text { lens } \\
\text { L2-90- } \\
\text { Cpy- } \\
\mathrm{Py}\end{array}$ & $\begin{array}{l}\mathrm{Cu}- \\
\text { rich } \\
\text { lens } \\
\text { L2-90- } \\
\text { Cpy- } \\
\text { Py }\end{array}$ & $\begin{array}{l}\mathrm{Cu}- \\
\text { rich } \\
\text { lens } \\
\text { L2-90- } \\
\text { Cpy- } \\
\text { Py }\end{array}$ & $\begin{array}{l}\text { Cu- } \\
\text { rich } \\
\text { lens } \\
\text { L2-90- } \\
\text { Cpy- } \\
\text { Py }\end{array}$ \\
\hline & 35.0 & 34.7 & 34.7 & 34.9 & 35.2 & 34.4 & 34.6 & 34.8 & 34.7 & 34.7 & 34.7 & 34.9 & 34.8 \\
\hline$S$ & 1 & 5 & 0 & 0 & 5 & 3 & 3 & 7 & 7 & 4 & 4 & 1 & 8 \\
\hline & 28.8 & 29.1 & 28.9 & 28.8 & 29.5 & 29.1 & 29.6 & 29.0 & 29.5 & 29.4 & 29.3 & 29.4 & 29.4 \\
\hline $\mathrm{Fe}$ & 1 & 7 & 8 & 3 & 3 & 3 & 7 & 9 & 8 & 1 & 1 & 1 & 3 \\
\hline As & 0.04 & 0.01 & 0.04 & - & - & 0.04 & - & 0.04 & 0.03 & 0.06 & 0.07 & & 0.02 \\
\hline Co & - & - & - & - & - & - & - & - & - & - & & 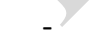 & - \\
\hline & 34.6 & 34.8 & 34.7 & 34.8 & 34.9 & 34.0 & 34.9 & 34.9 & 34.9 & 34.8 & 34.9 & 34.9 & 35.0 \\
\hline $\mathrm{Cu}$ & 6 & 3 & 8 & 6 & 5 & 9 & 4 & 8 & 5 & & 1 & 2 & 2 \\
\hline $\mathrm{Zn}$ & - & 0.05 & 0.42 & 0.06 & 0.01 & - & - & - & - & & & 0.01 & - \\
\hline $\mathrm{Bi}$ & - & - & - & - & - & 0.03 & 0.10 & 0.02 & & 0.11 & - & 0.01 & 0.11 \\
\hline $\mathrm{Cd}$ & - & 0.04 & 0.02 & - & 0.03 & - & - & 0.01 & 0.03 & & 0.02 & - & - \\
\hline Sn & - & 0.02 & - & 0.04 & 0.02 & 0.01 & 0.07 & 0.02 & - & 0.03 & - & - & - \\
\hline Total & 98.5 & 98.8 & 98.9 & 98.6 & 99.8 & 97.7 & 99.4 & 99.0 & 99.3 & 99.1 & 99.0 & 99.2 & 99.4 \\
\hline wt.\% & 1 & 7 & 5 & 9 & 0 & 2 & 2 & & 5 & 9 & 5 & 6 & 5 \\
\hline
\end{tabular}

\section{Pyrite}

\begin{tabular}{|c|c|c|c|c|c|c|c|c|c|c|}
\hline & $\begin{array}{l}\text { Zn-rich } \\
\text { lens } \\
\text { DF276-67 }\end{array}$ & $\begin{array}{l}\text { Cu-rich } \\
\text { lens } \\
\text { DS170- } \\
54.2 \\
\end{array}$ & $\begin{array}{l}\text { Cu-rich } \\
\text { lens } \\
\text { DS170- } \\
54.2\end{array}$ & $\begin{array}{l}\text { Cu-rich } \\
\text { lens } \\
\text { DS170- } \\
54.2 \\
\end{array}$ & $\begin{array}{l}\text { Cu-rich } \\
\text { lens } \\
\text { DS170-E7 }\end{array}$ & $\begin{array}{l}\text { Cu-rich } \\
\text { lens } \\
\text { DS170-E7 }\end{array}$ & $\begin{array}{l}\text { Cu-rich } \\
\text { lens } \\
\text { L2-90- } \\
\text { Cpy-Py } \\
\end{array}$ & $\begin{array}{l}\text { Cu-rich } \\
\text { lens } \\
\text { L2-90- } \\
\text { Cpy-Py }\end{array}$ & $\begin{array}{l}\text { Cu-rich } \\
\text { lens } \\
\text { L2-90- } \\
\text { Cpy-Py }\end{array}$ & $\begin{array}{l}\text { Cu-rich } \\
\text { lens } \\
\text { L2-90- } \\
\text { Cpy-Py } \\
\end{array}$ \\
\hline S & 54.55 & 52.27 & 51.92 & 52.05 & 53.52 & 52.80 & 51.93 & 51.33 & 52.19 & 52.63 \\
\hline $\mathrm{Fe}$ & 46.18 & 45.67 & 45.12 & 45.13 & 45.73 & 46.09 & 45.89 & 45.76 & 45.72 & 44.89 \\
\hline As & 0.03 & & & 0.03 & 0.02 & - & - & - & - & - \\
\hline Co & - & 0.03 & 0.03 & 0.07 & - & - & - & - & 0.01 & 0.02 \\
\hline $\mathrm{Cu}$ & 0.01 & 0.02 & - & - & 0.05 & - & 0.01 & 0.01 & 0.06 & 0.11 \\
\hline $\mathrm{Zn}$ & & 0.03 & - & 0.01 & - & - & - & - & - & 0.01 \\
\hline $\mathrm{Bi}$ & & 0.04 & 0.03 & - & - & 0.07 & - & - & - & 0.08 \\
\hline $\mathrm{Ni}$ & & 0.12 & 0.11 & 0.15 & 0.02 & 0.03 & 0.02 & 0.04 & 0.01 & 0.04 \\
\hline $\mathrm{Cd}$ & & - & - & 0.06 & 0.03 & 0.03 & - & - & 0.03 & - \\
\hline Sn & - & - & 0.01 & 0.02 & - & - & 0.02 & 0.02 & 0.01 & 0.03 \\
\hline total & 100.83 & 98.18 & 97.22 & 97.52 & 99.36 & 99.02 & 97.87 & 97.16 & 98.04 & 97.80 \\
\hline
\end{tabular}

\section{Arsenopyrite}

\begin{tabular}{|c|c|c|c|c|c|c|c|c|c|c|}
\hline & $\begin{array}{l}\text { Zn-rich } \\
\text { lens } \\
\text { DF311- } \\
122\end{array}$ & $\begin{array}{l}\text { Zn-rich } \\
\text { lens } \\
\text { DF311- } \\
122\end{array}$ & $\begin{array}{l}\text { Zn-rich } \\
\text { lens } \\
\text { DF311- } \\
122\end{array}$ & $\begin{array}{l}\text { Zn-rich } \\
\text { lens } \\
\text { DF311- } \\
122\end{array}$ & $\begin{array}{l}\text { Zn-rich } \\
\text { lens } \\
\text { DF276-67 }\end{array}$ & $\begin{array}{l}\text { Zn-rich } \\
\text { lens } \\
\text { DF276-67 }\end{array}$ & $\begin{array}{l}\text { Cu-rich } \\
\text { lens } \\
\text { L2-90- } \\
\text { Cpy-Py }\end{array}$ & $\begin{array}{l}\text { Cu-rich } \\
\text { lens } \\
\text { L2-90- } \\
\text { Cpy-Py }\end{array}$ & $\begin{array}{l}\text { Cu-rich } \\
\text { lens } \\
\text { L2-90- } \\
\text { Cpy-Py }\end{array}$ & $\begin{array}{l}\text { Cu-rich } \\
\text { lens } \\
\text { L2-90- } \\
\text { Cpy-Py }\end{array}$ \\
\hline$S$ & 19.98 & 20.02 & 19.92 & 19.68 & 20.04 & 20.14 & 19.58 & 19.24 & 19.50 & 19.85 \\
\hline $\mathrm{Fe}$ & 33.27 & 33.37 & 33.47 & 33.68 & 34.31 & 34.22 & 34.28 & 34.19 & 33.74 & 33.71 \\
\hline As & 44.45 & 44.25 & 44.45 & 44.58 & 44.27 & 43.81 & 44.71 & 43.80 & 45.01 & 44.36 \\
\hline
\end{tabular}


Downloaded from http://sp.lyellcollection.org/ at Universite Nice Sophia Antipolis (ISTEX) on February 6, 2020

\begin{tabular}{|c|c|c|c|c|c|c|c|c|c|c|}
\hline Co & 0.02 & 0.03 & 0.05 & 0.06 & - & - & - & - & - & 0.07 \\
\hline $\mathrm{Cu}$ & - & - & 0.01 & 0.04 & - & - & 0.30 & 0.25 & 0.97 & 0.80 \\
\hline $\mathrm{Zn}$ & 0.10 & - & 0.02 & - & 0.56 & 0.69 & 0.01 & - & 0.01 & 0.02 \\
\hline $\mathrm{Ni}$ & 0.21 & 0.36 & 0.04 & 0.18 & 0.02 & 0.03 & - & - & 0.02 & 0.01 \\
\hline $\mathrm{Cd}$ & 0.01 & 0.02 & - & 0.01 & - & 0.01 & - & - & - & 0.05 \\
\hline $\mathrm{Sb}$ & 0.04 & - & 0.02 & 0.14 & 0.60 & 0.24 & 0.07 & 0.07 & 0.06 & 0.09 \\
\hline total & 98.08 & 98.04 & 97.97 & 98.37 & 99.82 & 99.13 & 98.94 & 97.55 & 99.32 & 98.97 \\
\hline As cat & 32.63 & 32.46 & 32.67 & 32.73 & 32.04 & 31.80 & 32.67 & 32.44 & 32.84 & 32.34 \\
\hline
\end{tabular}

\section{Cobaltite}

\begin{tabular}{|c|c|c|c|}
\hline & $\begin{array}{l}\text { Cu-rich } \\
\text { lens } \\
\text { DS161- } \\
90.5\end{array}$ & $\begin{array}{l}\text { Cu-rich } \\
\text { lens } \\
\text { DS161- } \\
90.5\end{array}$ & $\begin{array}{l}\text { Cu-rich } \\
\text { lens } \\
\text { DS161- } \\
90.5 \\
\end{array}$ \\
\hline$S$ & 19.47 & 20.14 & 19.24 \\
\hline $\mathrm{Fe}$ & 2.48 & 2.42 & 2.36 \\
\hline As & 44.08 & 44.10 & 44.64 \\
\hline Co & 33.23 & 29.83 & 32.87 \\
\hline $\mathrm{Cu}$ & - & 0.09 & 0.02 \\
\hline $\mathrm{Zn}$ & - & - & - \\
\hline $\mathrm{Bi}$ & - & - & - \\
\hline $\mathrm{Ni}$ & - & 4.09 & 0.50 \\
\hline Total & 99.27 & 100.67 & 99.62 \\
\hline As cat & 32.61 & 32.05 & 33.02 \\
\hline
\end{tabular}


Downloaded from http://sp.lyellcollection.org/ at Universite Nice Sophia Antipolis (ISTEX) on February 6, 2020

Table 2. Atomic absorption analysis of drill core DF318

\begin{tabular}{|c|c|c|c|c|c|c|c|c|}
\hline Depth (m) & Zn wt. \% & Pb wt. \% & Cu wt. \% & Fe wt. \% & Ag ppm & Co ppm & As $\%$ & Au ppm \\
\hline 87.7 & 0.03 & 0.074 & 0.009 & na* & 208 & 22 & 0.025 & $<\mathrm{dl}$ \\
\hline 88.4 & 10.26 & 3.34 & 0.22 & na & 234 & 31 & 1.05 & $<\mathrm{dl}$ \\
\hline 88.9 & 0.03 & 0.02 & 0.094 & na & 78 & 11 & 0.014 & $<\mathrm{dl}$ \\
\hline 89.8 & 0.39 & 0.27 & 0.66 & na & 16 & 21 & 0.04 & $<\mathrm{dl}$ \\
\hline 90.3 & 12.65 & 4.99 & 0.19 & na & 40 & 13 & 0.92 & 0.08 \\
\hline 91.3 & 11.05 & 1.74 & 0.29 & na & 32 & 28 & 0.87 & $<\mathrm{dl}$ \\
\hline 92.3 & 10.38 & 0.64 & 0.29 & na & 32 & 30 & 0.04 & \\
\hline 92.65 & 9.18 & 0.52 & 0.29 & na & 28 & $<\mathrm{dl}$ & 0.09 & $<\mathrm{dl}$ \\
\hline 93 & 12.1 & 3.3 & 0.37 & na & 35 & 26 & 0.96 & $<\mathrm{dl}$ \\
\hline 94 & 11.27 & 2.27 & 0.38 & na & 35 & 33 & 1.08 & $<\mathrm{dl}$ \\
\hline 95 & 12.3 & 4.45 & 0.34 & na & 35 & 21 & 1.4 & $<\mathrm{dl}$ \\
\hline 96 & 11.28 & 5.55 & 0.33 & na & 42 & 17 & 0.75 & $<\mathrm{dl}$ \\
\hline 97 & 7.44 & 5.66 & 0.28 & na & 45 & 24 & 1.09 & $<\mathrm{dl}$ \\
\hline 97.4 & 0.89 & 0.68 & 0.075 & na & 17 & 26 & 0.059 & $<\mathrm{dl}$ \\
\hline 98 & 1.44 & 0.48 & 0.037 & na & 16 & 18 & 0.013 & $<\mathrm{dl}$ \\
\hline 99 & 1.94 & 0.58 & 0.041 & 8.92 & 6 & 22 & 0.024 & $<\mathrm{dl}$ \\
\hline 100 & 2.24 & 0.48 & 0.041 & 9.51 & 8 & 16 & 0.019 & 0.09 \\
\hline 101 & 1.88 & 0.29 & 0.041 & 8.66 & 8 & 24 & 0.055 & $<\mathrm{dl}$ \\
\hline 102 & 1.52 & 0.16 & 0.073 & 7.64 & 7 & 42 & 0.421 & $<\mathrm{dl}$ \\
\hline 102.5 & 12.26 & 0.77 & 0.27 & 40.39 & 20 & 41 & 0.91 & 0.06 \\
\hline 103.5 & 12.43 & 2.96 & 0.32 & 39.82 & 25 & 45 & 0.8 & $<\mathrm{dl}$ \\
\hline 104.5 & 12.04 & 7.66 & 0.3 & 38.77 & 28 & 57 & 1.03 & $<\mathrm{dl}$ \\
\hline 105.7 & 1.07 & 0.18 & 0.024 & 7.8 & 8 & 114 & 0.004 & $<\mathrm{dl}$ \\
\hline 106.7 & 0.85 & 0.066 & 0.044 & 8.16 & 12 & 74 & 0.007 & $<\mathrm{dl}$ \\
\hline 107.95 & 10.98 & 3.19 & 0.11 & 40.12 & 24 & 63 & 0.68 & $<\mathrm{dl}$ \\
\hline 108.3 & 0.29 & 0.014 & 0.062 & 7.84 & 8 & 55 & $<\mathrm{dl}$ & 0.07 \\
\hline 109.3 & 0.98 & 0.008 & 0.019 & 8.08 & 7 & 64 & 0.004 & $<\mathrm{dl}$ \\
\hline 110 & 13.72 & 0.52 & 0.17 & 31.51 & 13 & 143 & 0.24 & $<\mathrm{dl}$ \\
\hline 110.43 & 0.41 & 0.012 & 0.22 & 10.11 & 7 & 71 & 0.01 & $<\mathrm{dl}$ \\
\hline 110.85 & 10.09 & 0.012 & 0.62 & 22.12 & 14 & 137 & 0.14 & 0.09 \\
\hline 111 & 1.12 & 0.005 & 0.06 & 7.7 & 10 & 85 & $<\mathrm{dl}$ & 0.08 \\
\hline 181 & 0.017 & 0.004 & 0.009 & 11.15 & 8 & 368 & 0.062 & $<\mathrm{dl}$ \\
\hline 182 & 0.031 & 0.011 & 0.51 & 43.46 & 5 & 599 & 0.04 & 0.19 \\
\hline 182.3 & 0.022 & 0.011 & 0.73 & 58.39 & 6 & 601 & 0.04 & 0.31 \\
\hline 183.5 & $<\mathrm{d} \mid 4$ & 0.019 & 0.98 & 58.22 & 8 & 605 & 0.04 & 0.29 \\
\hline 184.5 & 0.19 & 0.045 & 0.67 & 58.41 & 8 & 611 & 0.04 & 0.31 \\
\hline 185.5 & 0.12 & $<\mathrm{d} \mid 4$ & 0.84 & 58.2 & 7 & 614 & 0.05 & 0.59 \\
\hline 186.53 & 0.04 & 0.022 & 0.69 & 59.23 & 5 & 702 & 0.04 & 0.93 \\
\hline 187.5 & 0.017 & 0.01 & 0.83 & 57.62 & 4 & 670 & 0.04 & 0.56 \\
\hline 188.5 & 0.012 & 0.008 & 0.66 & 58.67 & 3 & 662 & 0.04 & 0.36 \\
\hline 189.5 & 0.016 & 0.01 & 1.13 & 58.74 & 5 & 729 & 0.05 & 0.57 \\
\hline
\end{tabular}


Downloaded from http://sp.lyellcollection.org/ at Universite Nice Sophia Antipolis (ISTEX) on February 6, 2020

\begin{tabular}{lcccccccc}
190.5 & $<\mathrm{dl} 1$ & 0.018 & 2.45 & 54.74 & 4 & 906 & 0.07 & 0.48 \\
191.5 & 0.048 & 0.022 & 1.76 & 55.38 & 5 & 1200 & 0.1 & 0.32 \\
192.52 & 0.08 & 0.037 & 1 & 53.74 & 4 & 804 & 0.05 & 0.33 \\
193.5 & 0.088 & 0.043 & 0.97 & 48.48 & 6 & 1300 & 0.11 & 0.19 \\
194.5 & 1.62 & 0.55 & 1.33 & 44.45 & 4 & 687 & 0.14 & $<\mathrm{dl}$ \\
194.8 & 0.024 & 0.004 & 0.004 & 16.58 & 3 & $<\mathrm{dl}$ & 0.012 & 0.25 \\
231 & 0.027 & 0.011 & 0.21 & 20.34 & 5 & 73 & 0.01 & $<\mathrm{dl}$ \\
231.9 & 0.008 & 0.011 & 0.24 & 44.01 & 8 & 616 & 0.02 & $<\mathrm{dl}$ \\
233.4 & 0.014 & 0.01 & 0.082 & 25.35 & 7 & 211 & $<\mathrm{dl}$ & $<\mathrm{dl}$ \\
234.1 & 0.012 & 0.014 & 0.7 & 53.16 & 9 & 967 & 0.05 & 0.44 \\
234.7 & 0.018 & 0.025 & 0.32 & 25.35 & 9 & 200 & $<\mathrm{dl}$ & 0.2 \\
236.4 & 0.009 & 0.005 & 0.019 & 11.47 & 5 & 39 & $<\mathrm{dl}$ & $<\mathrm{dl}$ \\
237.3 & 0.06 & 0.041 & 0.51 & 47.76 & 13 & 751 & 0.02 & $<\mathrm{dl}$ \\
238.5 & 0.006 & 0.009 & 0.024 & $1<\mathrm{dl}$ & 6 & 41 & 0.015 & 0.08 \\
\hline
\end{tabular}

* not analysed

Detection limits ( $\mathrm{dl}$ ) $0.001 \%$ for $\mathrm{Zn}, \mathrm{Pb}, \mathrm{Cu}$ and Fe, $0.003 \%$ for As, 1 ppm for Ag, 10 ppm for Co and 0.05 ppm for Au 
Downloaded from http://sp.lyellcollection.org/ at Universite Nice Sophia Antipolis (ISTEX) on February 6, 2020
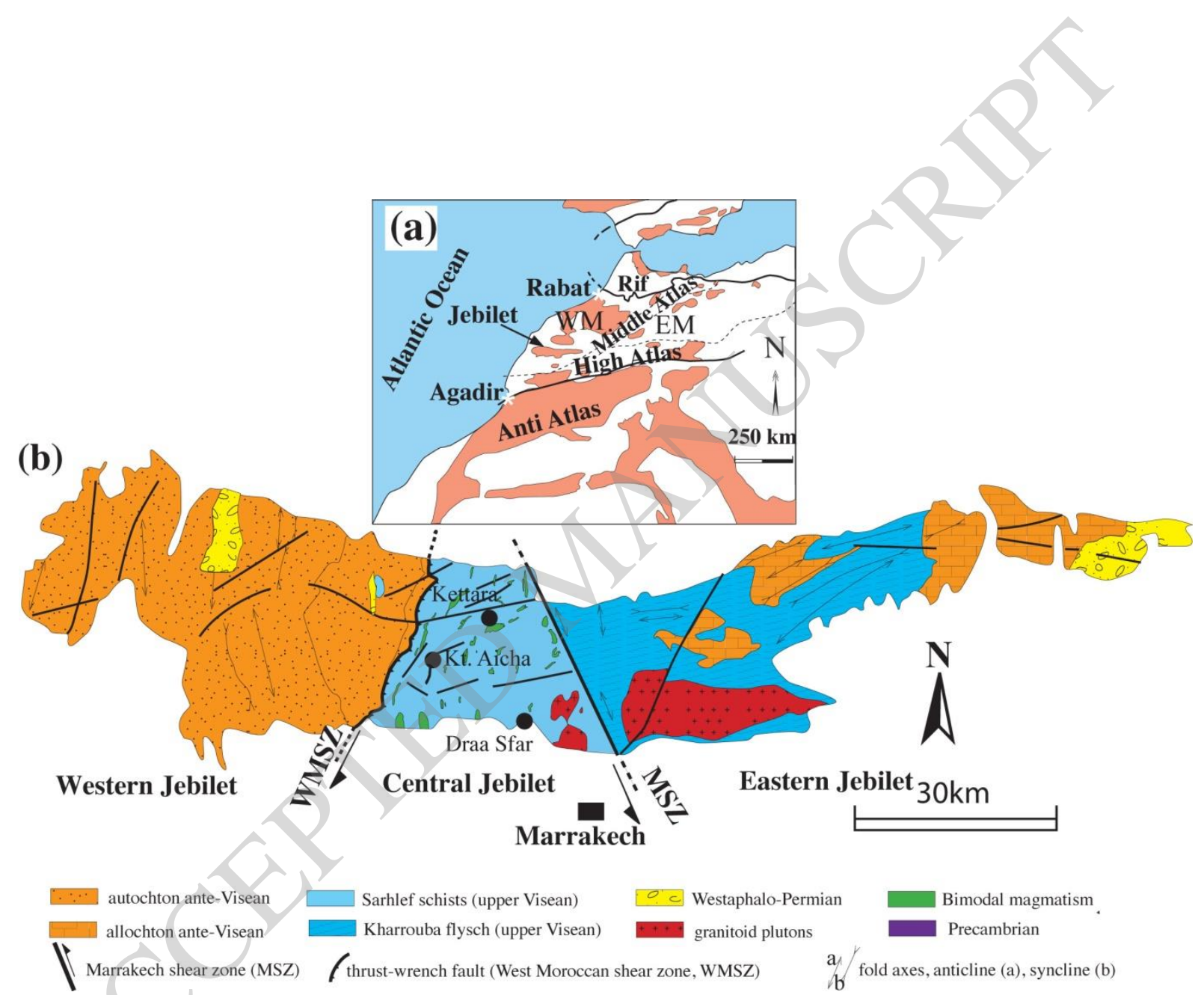
Downloaded from http://sp.lyellcollection.org/ at Universite Nice Sophia Antipolis (ISTEX) on February 6,

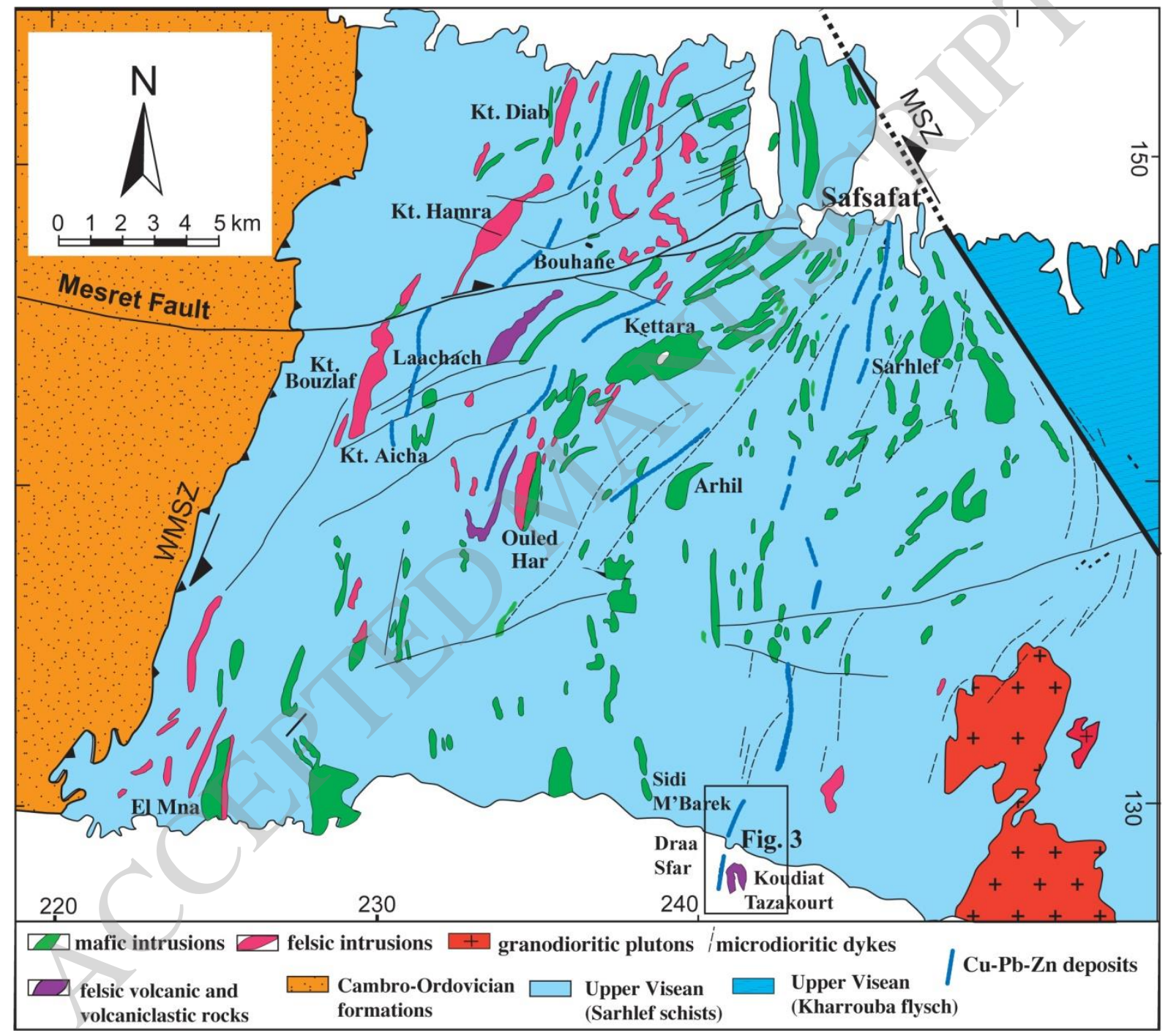


Downloaded from http://sp.lyellcollection.org/ at Universite Nice Sophia Antipolis (ISTEX) on February 6,

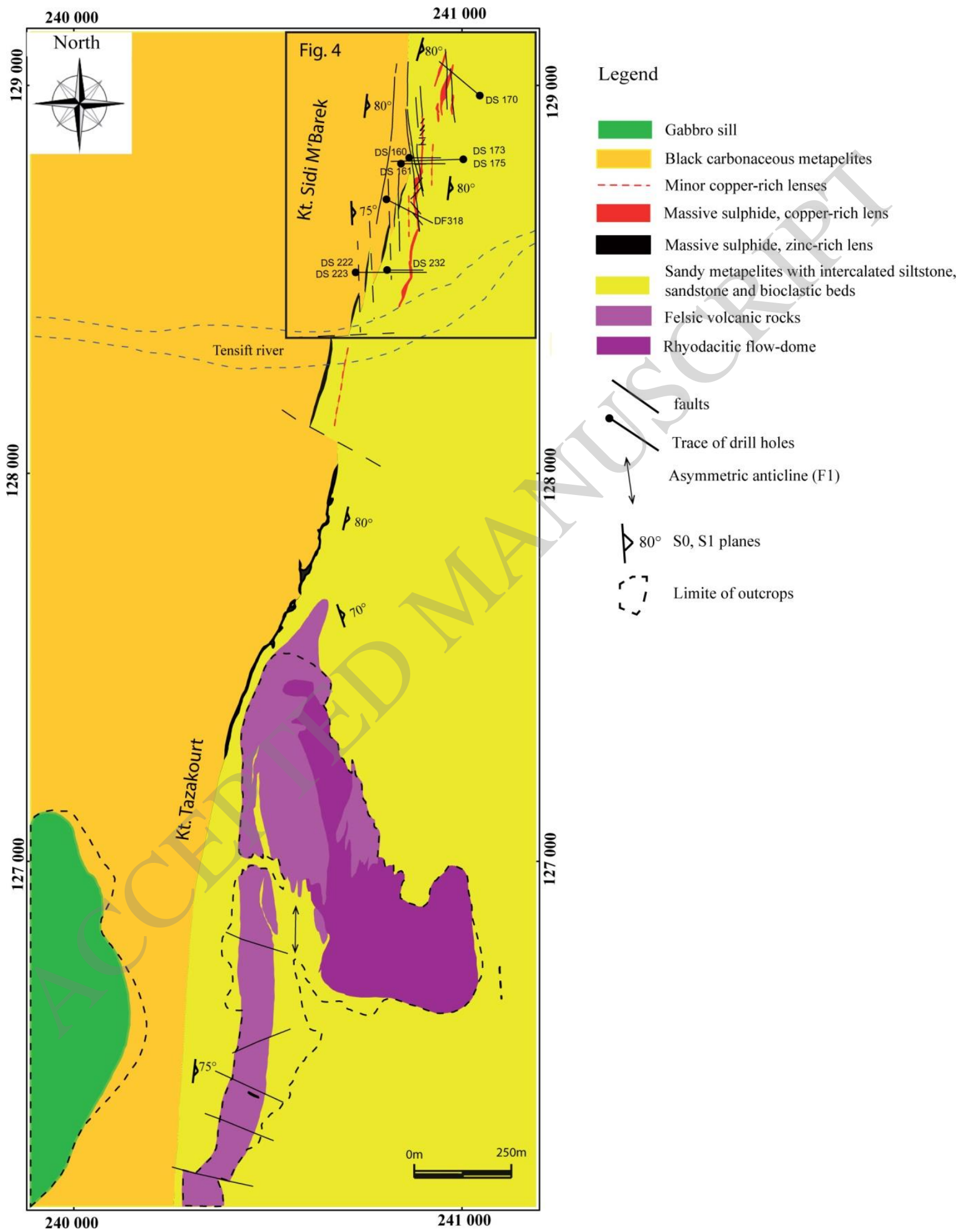


Downloaded from http://sp.lyellcollection.org/ at Universite Nice Sophia Antipolis (ISTEX) on February 6,

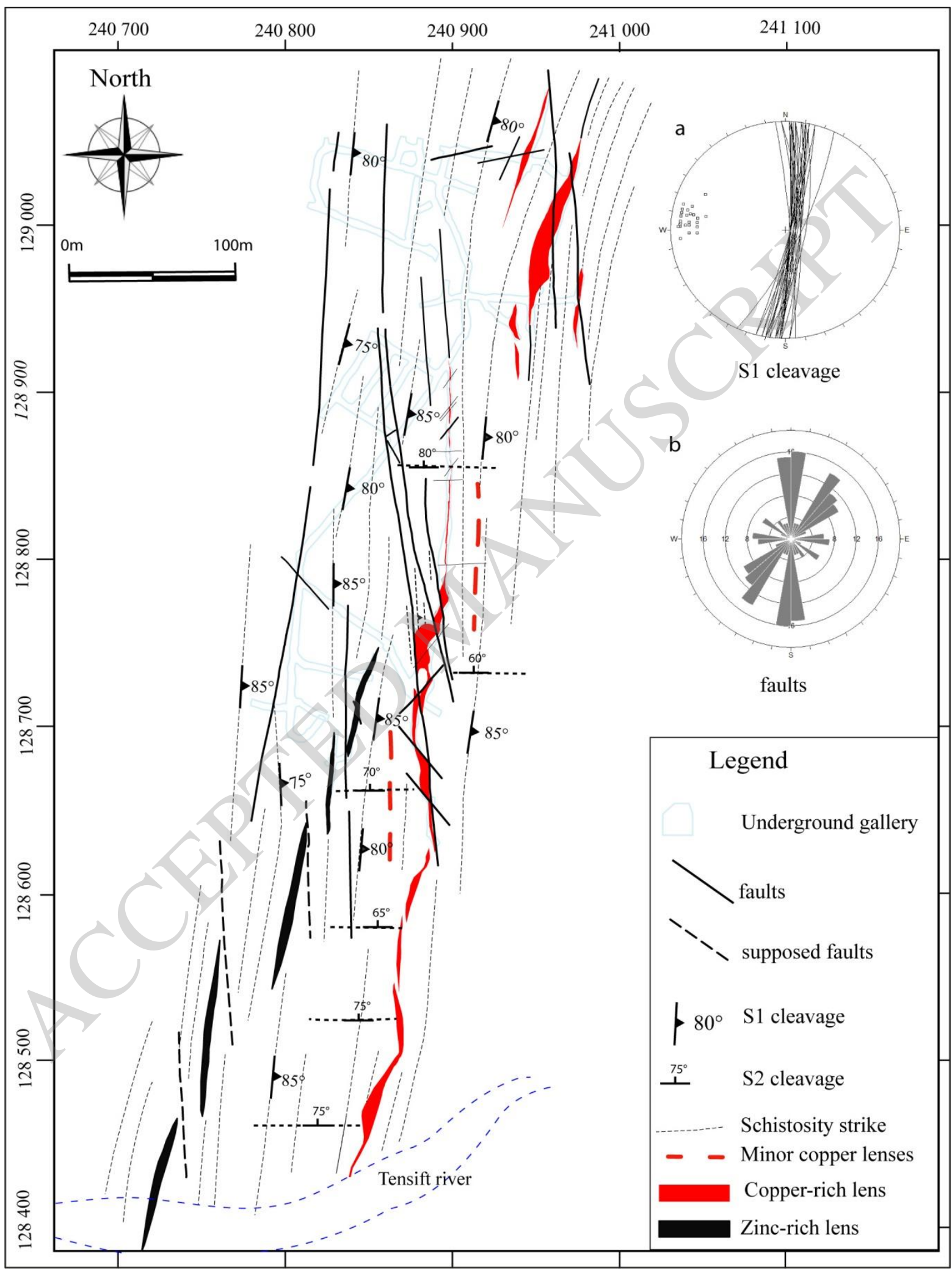


Downloaded from http://sp.lyellcollection.org/ at Universite Nice Sophia Antipolis (ISTEX) on February 6, 2020

DS 170

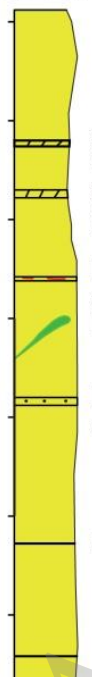

Sandy metapelites

(Po, Cpy)-bearing fault

quartz and sulphide

(Po, Cpy)-bearing fault

Disseminated

sulphides (Cpy, Po)

Doleritic dyke

Disseminated

sulphides (Cpy, Po)

Bioclastic bed

Bioclastic bed
DS 223

Overburden

metapelites

Sulphide horizon ( $\mathrm{Zn}$ lens)

Cu-rich massive sulphide

Cu-rich massive sulphide

(Po, Ccy)

sulphides (Cpy, Po)

Disseminated

sulphides

Sandy metapelites

Semi-massive ore

(Po, Cpy)

Doleritic dyke

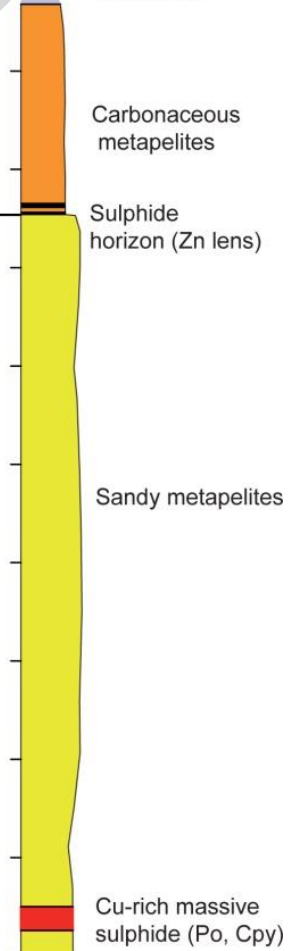


Downloaded from http://sp.lyellcollection.org/ at Universite Nice Sophia Antipolis (ISTEX) on February 6,
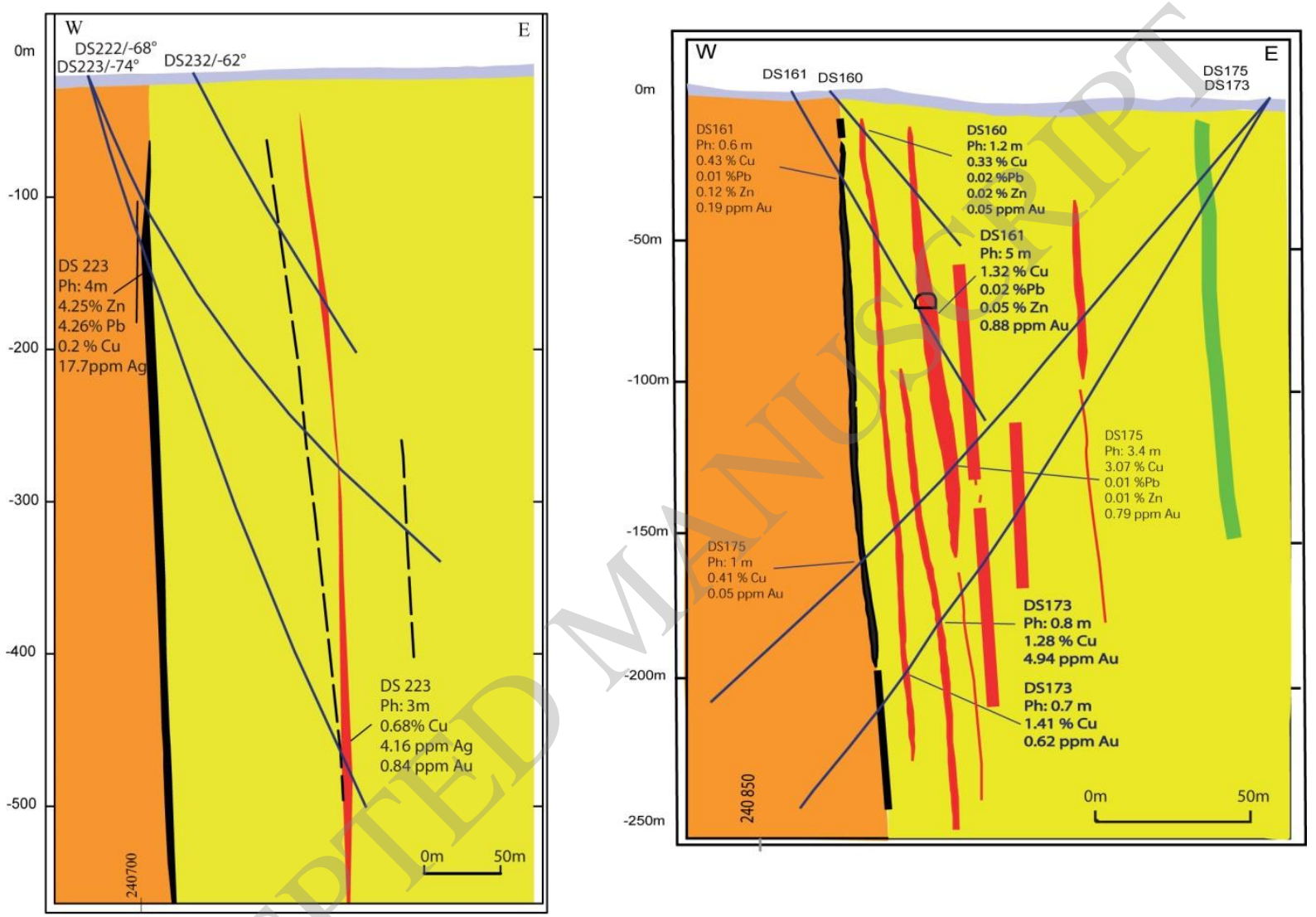

\section{Overburden}

Doleritic dyke

Black carbonaceous metapelites

Massive sulphide, copper-rich lens

Massive sulphide, zinc-rich lens

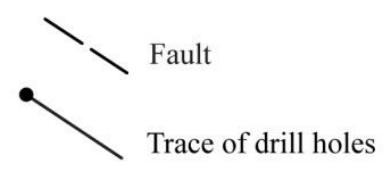

Sandy metapelites with intercalated siltstone, sandstone and bioclastic beds 
Downloaded from http://sp.lyellcollection.org/ at Universite Nice Sophia Antipolis (ISTEX) on February 6,
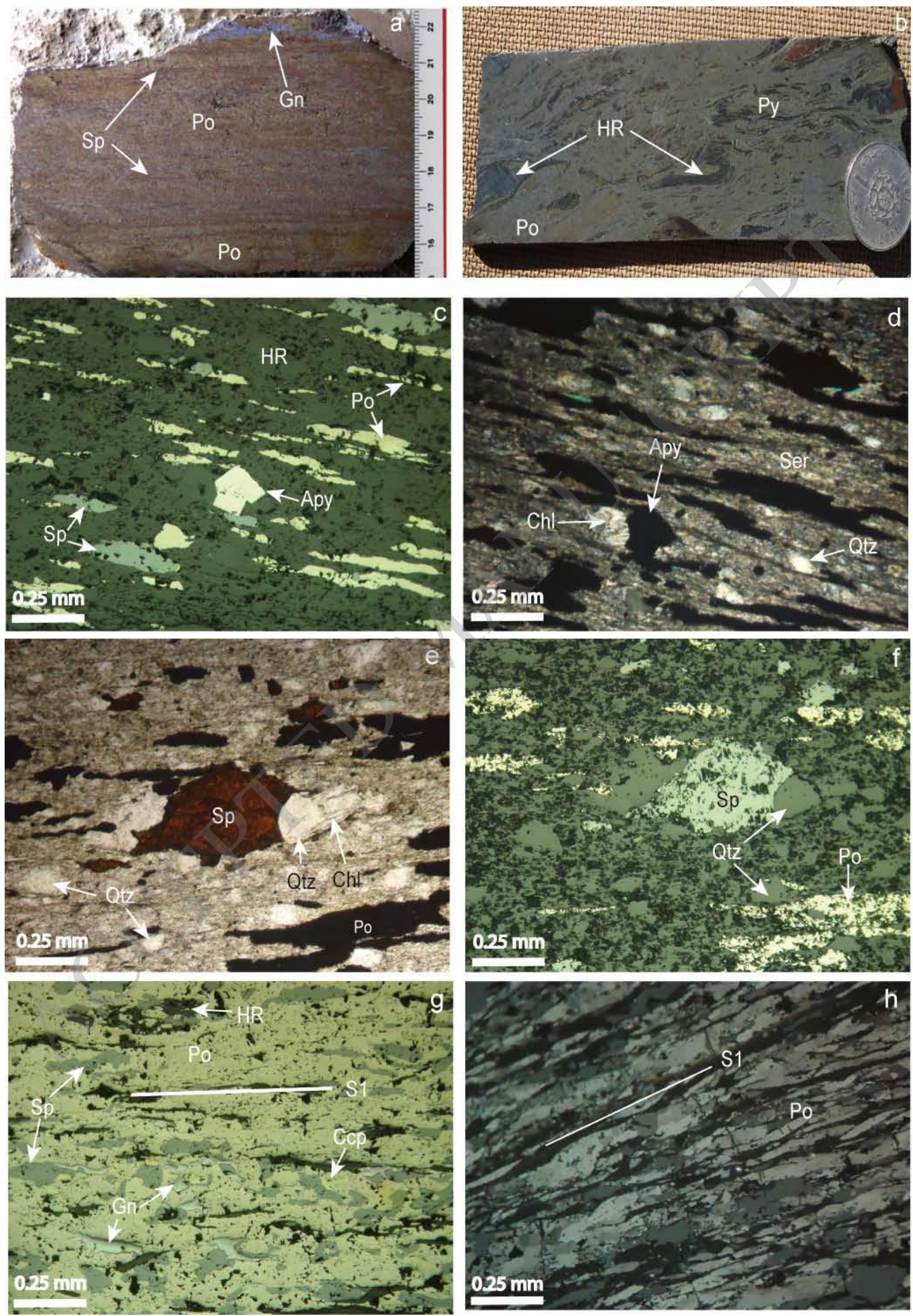
Downloaded from http://sp.lyellcollection.org/ at Universite Nice Sophia Antipolis (ISTEX) on February 6,
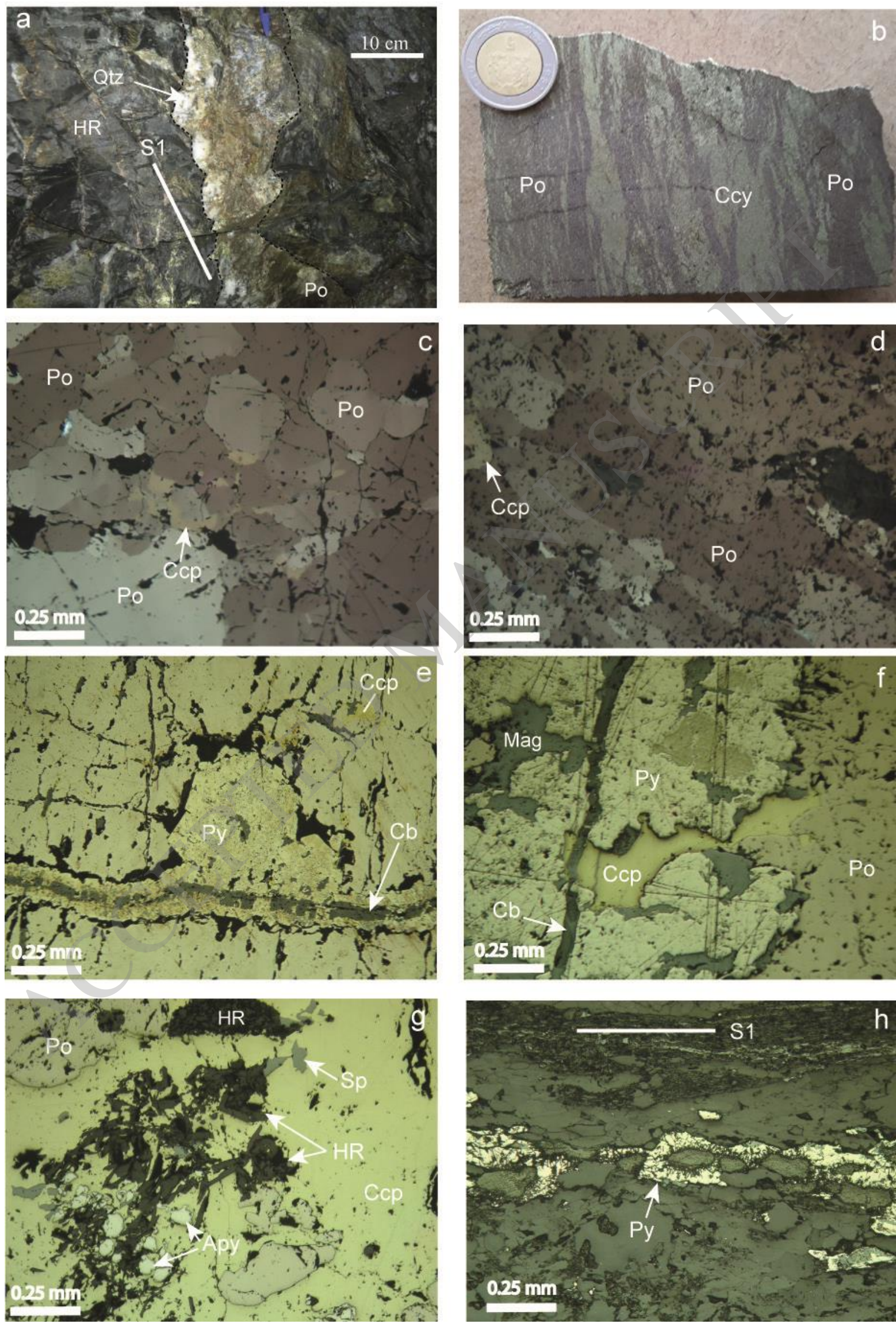
Downloaded from http://sp.lyellcollection.org/ at Universite Nice Sophia Antipolis (ISTEX) on February 6, 2020

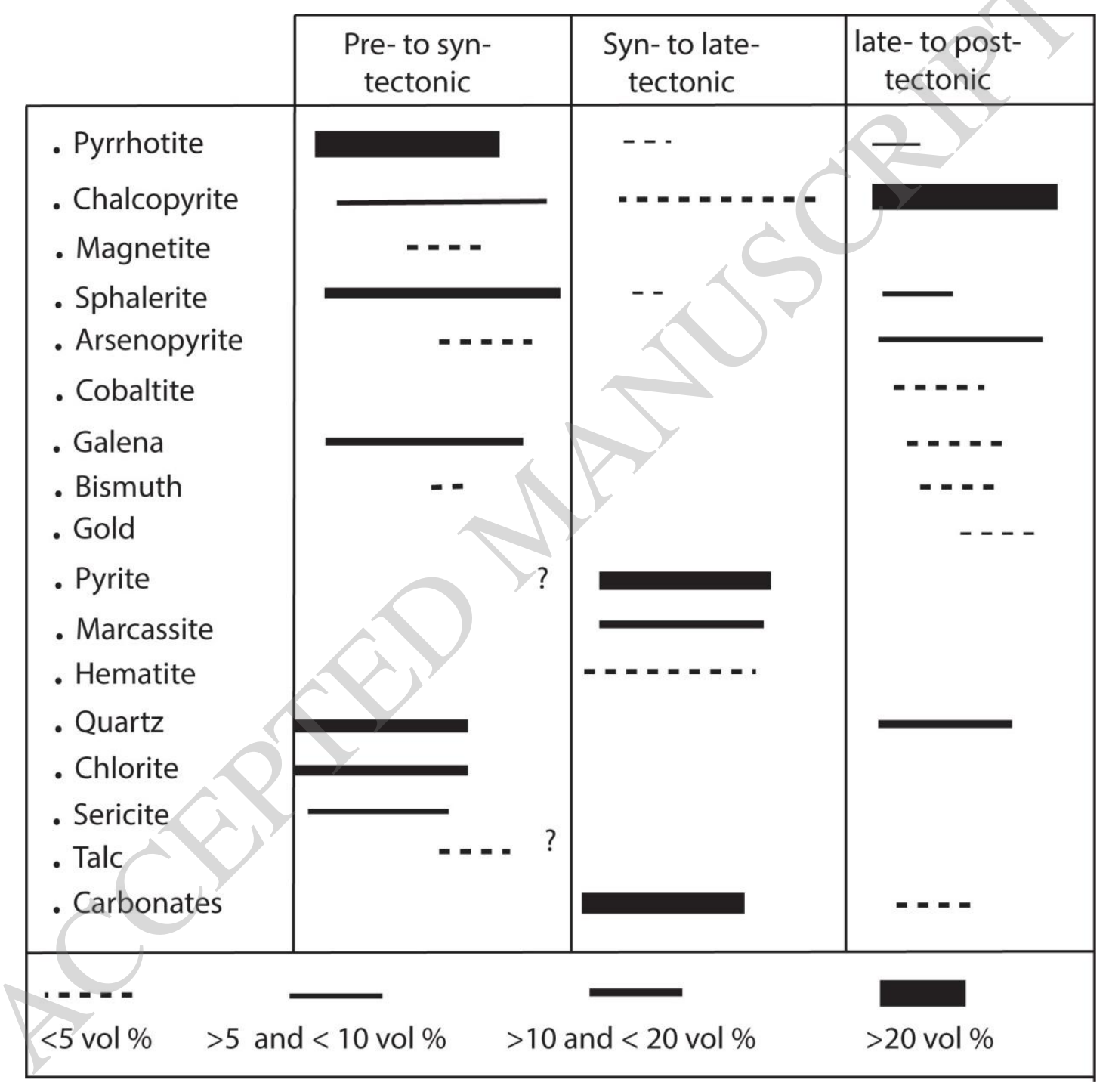


Downloaded from http://sp.lyellcollection.org/ at Universite Nice Sophia Antipolis (ISTEX) on February 6, 2020
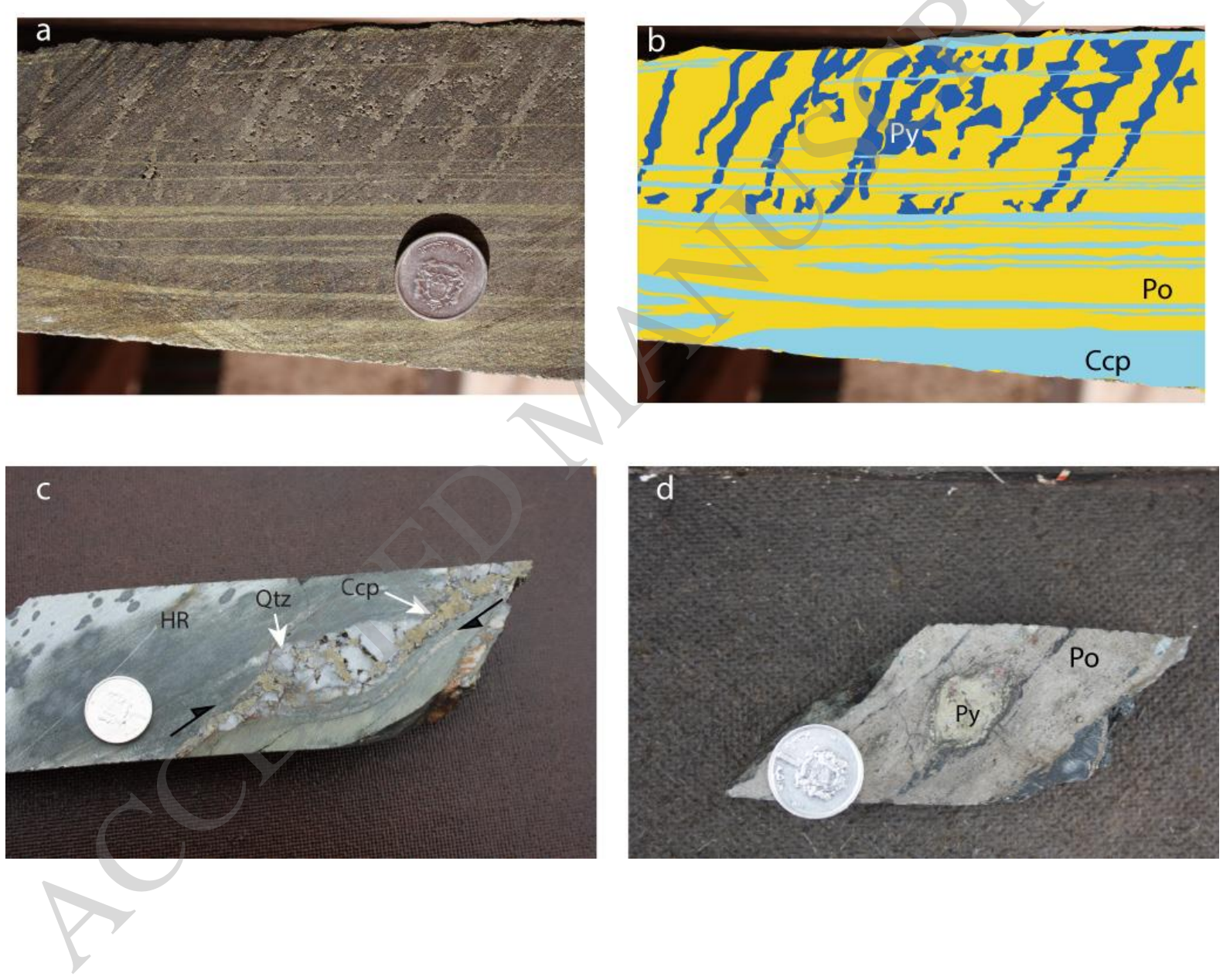
Downloaded from http://sp.lyellcollection.org/ at Universite Nice Sophia Antipolis (ISTEX) on February 6, 2020
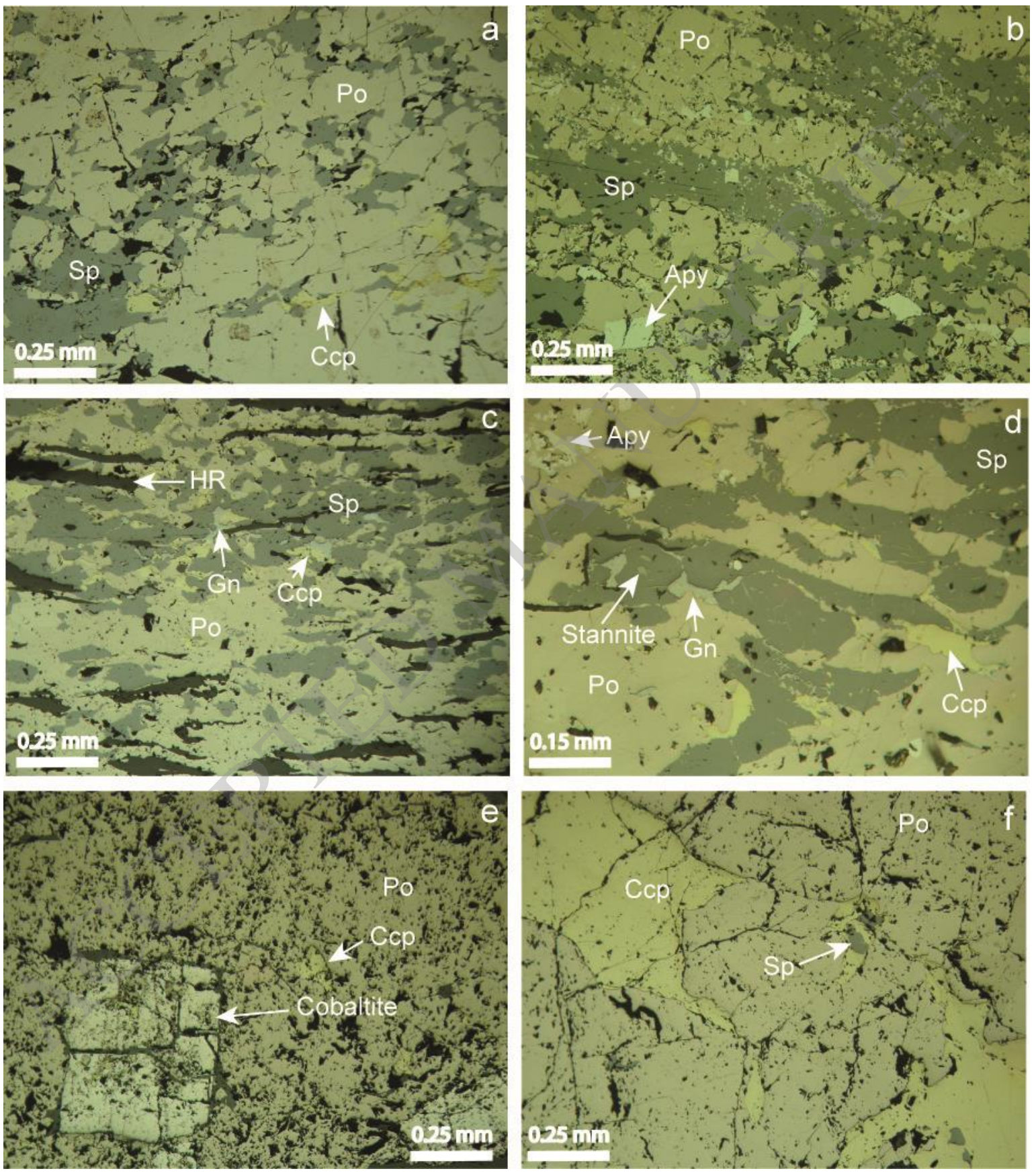

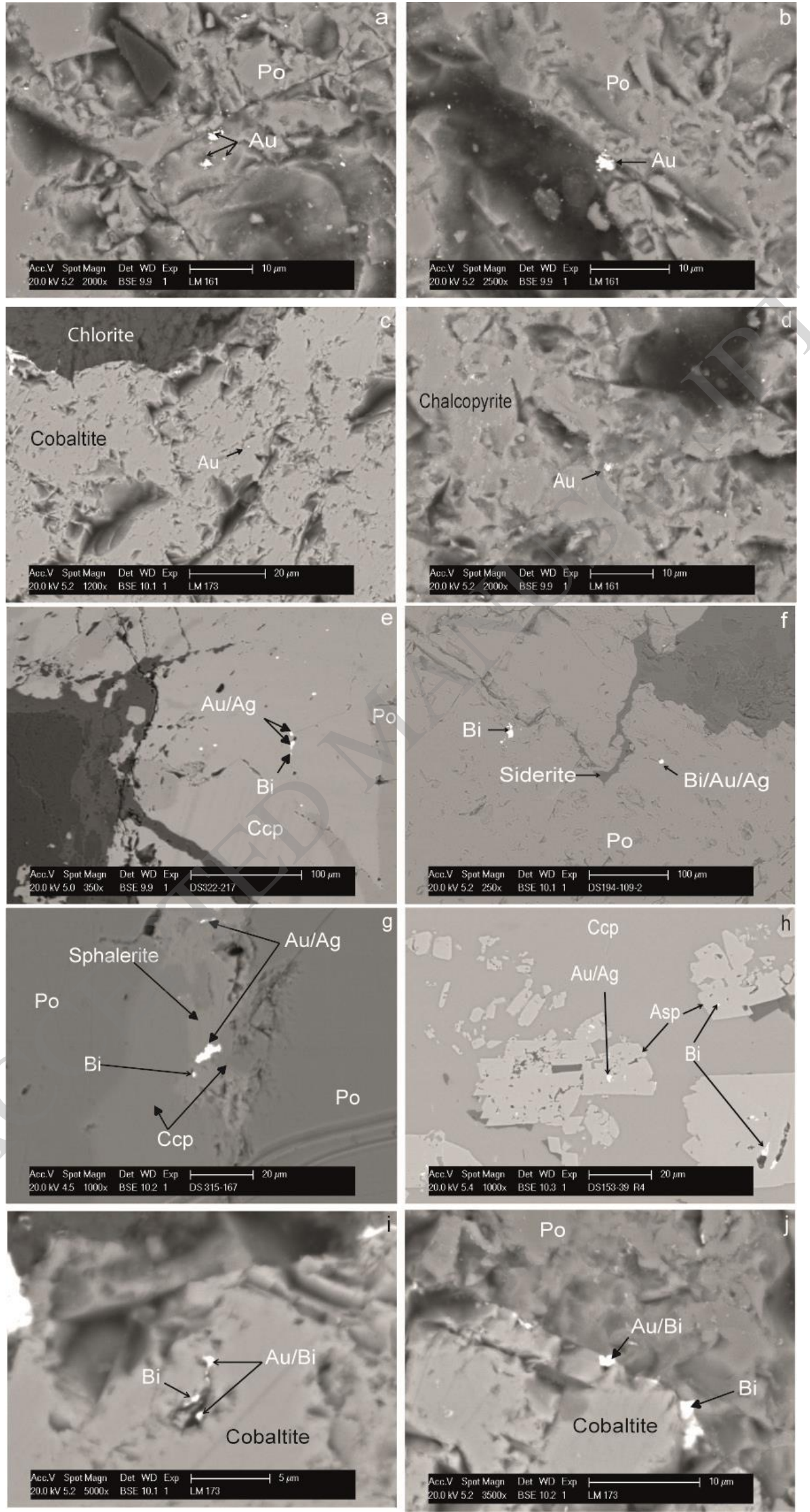
Downloaded from http://sp.lyellcollection.org/ at Universite Nice Sophia Antipolis (ISTEX) on February 6, 2020
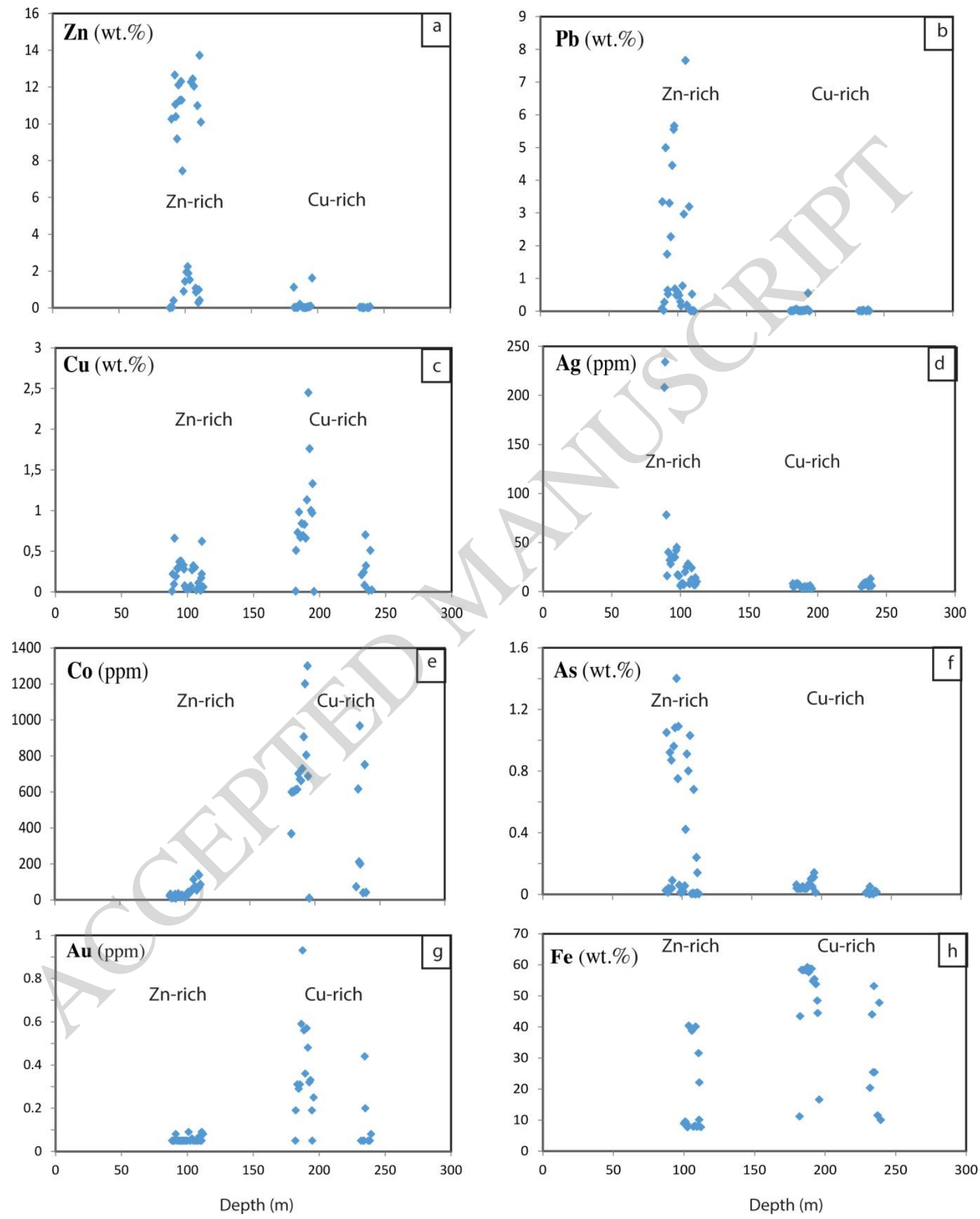
Downloaded from http://sp.lyellcollection.org/ at Universite Nice Sophia Antipolis (ISTEX) on February 6, 2020

a
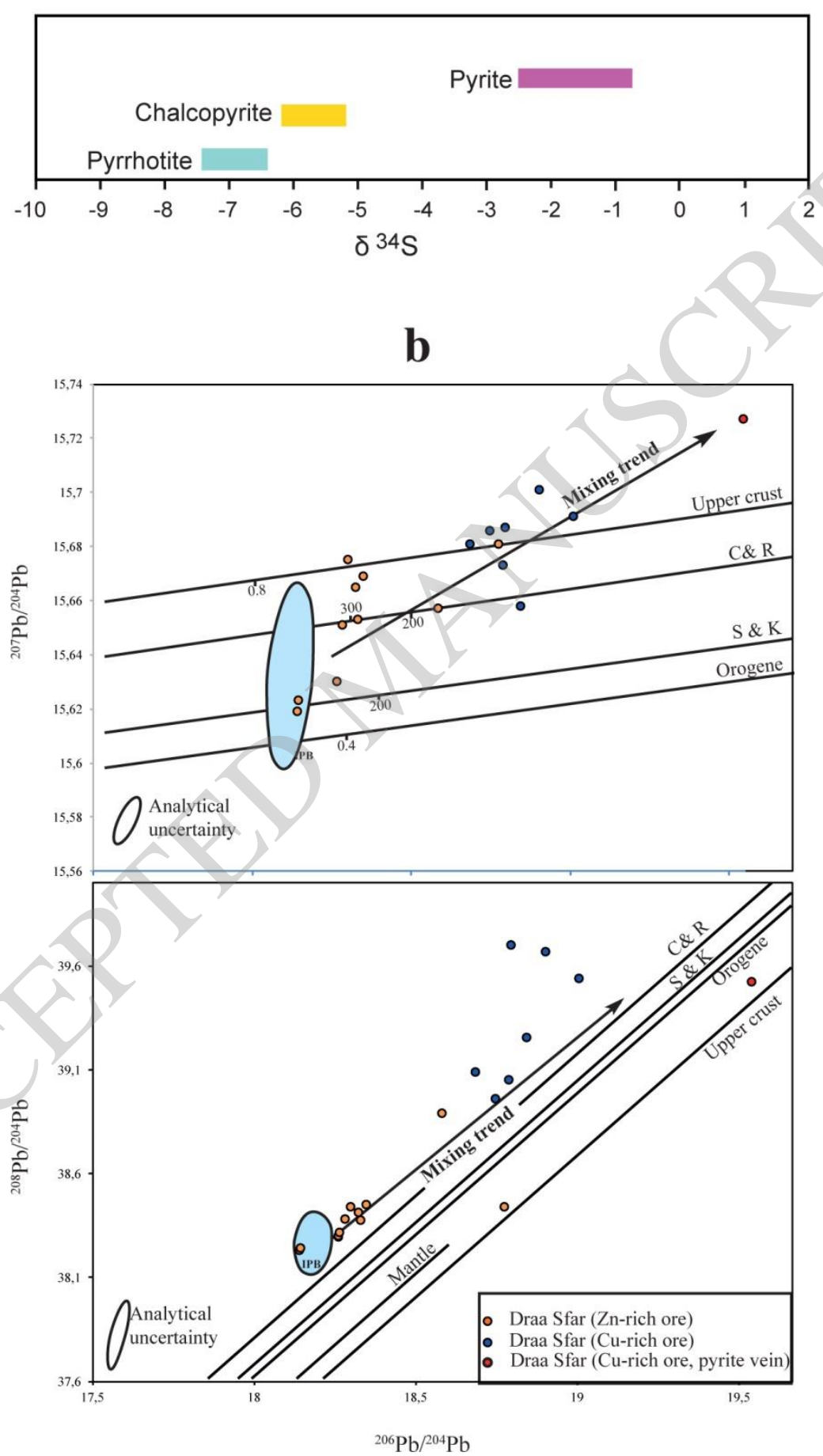
Downloaded from http://sp.lyellcollection.org/ at Universite Nice Sophia Antipolis (ISTEX) on February 6, 2020

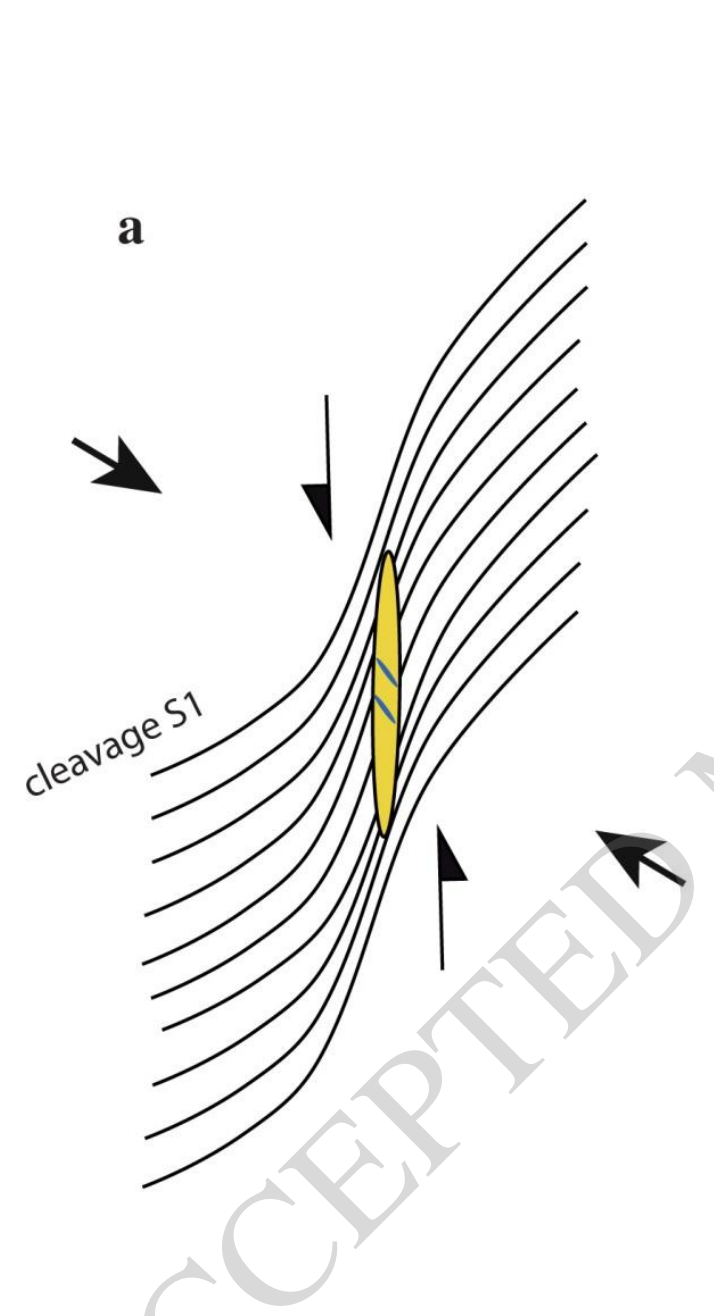

Stage 1

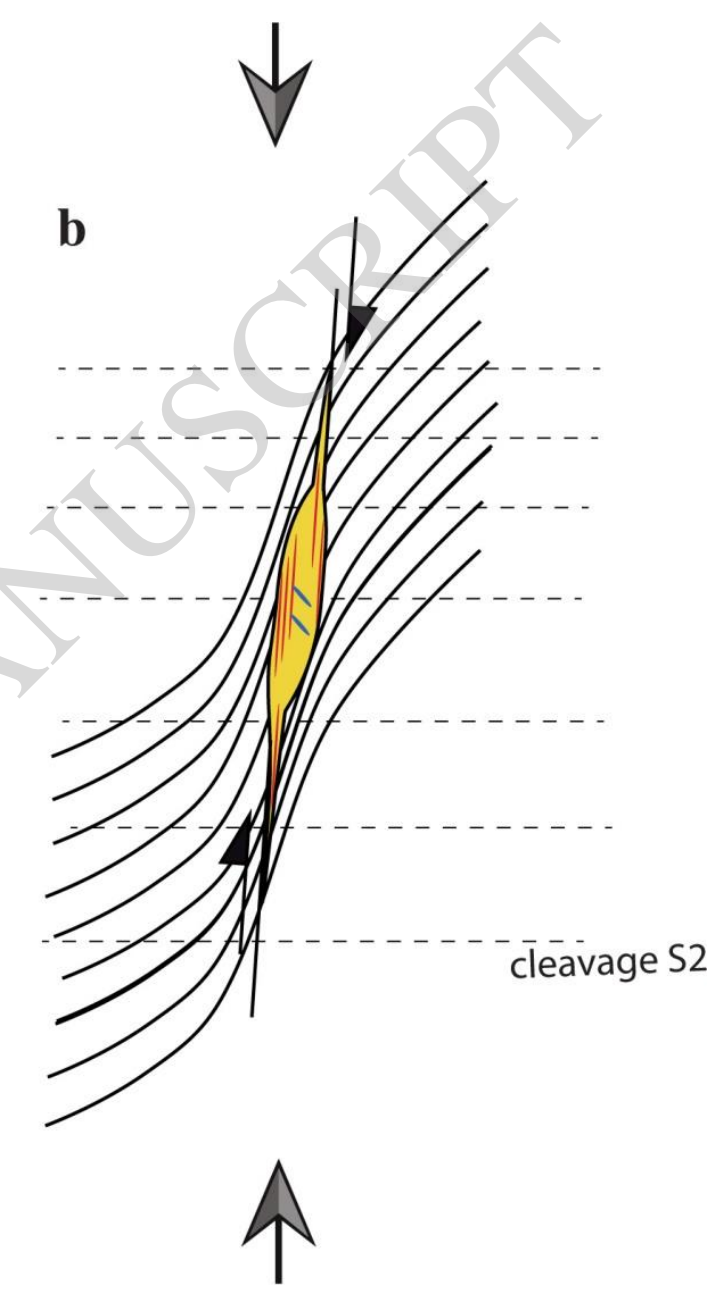

Stage 2 